\title{
Internalization and desensitization of adenosine receptors
}

\author{
Elisabeth C. Klaasse • Adriaan P. IJzerman • \\ Willem J. de Grip • Margot W. Beukers
}

Received: 20 July 2007 / Accepted: 2 October 2007 / Published online: 13 November 2007

(C) Springer Science + Business Media B.V. 2007

\begin{abstract}
Until now, more than 800 distinct $G$ proteincoupled receptors (GPCRs) have been identified in the human genome. The four subtypes of the adenosine receptor $\left(\mathrm{A}_{1}, \mathrm{~A}_{2 \mathrm{~A}}, \mathrm{~A}_{2 \mathrm{~B}}\right.$ and $\mathrm{A}_{3}$ receptor) belong to this large family of GPCRs that represent the most widely targeted pharmacological protein class. Since adenosine receptors are widespread throughout the body and involved in a variety of physiological processes and diseases, there is great interest in understanding how the different subtypes are regulated, as a basis for designing therapeutic drugs that either avoid or make use of this regulation. The major GPCR regulatory pathway involves phosphorylation of activated receptors by $\mathrm{G}$ protein-coupled receptor kinases (GRKs), a process that is followed by binding of arrestin proteins. This prevents receptors from activating downstream heterotrimeric $G$ protein pathways, but at the same time allows activation of arrestin-dependent signalling pathways. Upon agonist treatment, adenosine receptor subtypes are differently regulated. For instance, the $A_{1}$ Rs are not (readily) phosphorylated and internalize slowly, showing a typical half-life of several hours, whereas the $A_{2 A} R$ and $A_{2 B} R$ undergo much faster downregulation, usually shorter than $1 \mathrm{~h}$. The $A_{3} R$ is subject to even faster
\end{abstract}

E. C. Klaasse · A. P. IJzerman $(\bowtie) \cdot$ W. J. de Grip •

M. W. Beukers

Department of Medicinal Chemistry, Leiden/Amsterdam Center for Drug Research, Leiden University,

Einsteinweg 55, P.O. Box 9502,

2300 RA Leiden, The Netherlands

e-mail: ijzerman@lacdr.leidenuniv.nl

W. J. de Grip

Department of Biophysical Organic Chemistry,

Leiden Institute of Chemistry, Leiden/Amsterdam

Center for Drug Research, Leiden University,

Leiden, The Netherlands downregulation, often a matter of minutes. The fast desensitization of the $A_{3} R$ after agonist exposure may be therapeutically equivalent to antagonist occupancy of the receptor. This review describes the process of desensitization and internalization of the different adenosine subtypes in cell systems, tissues and in vivo studies. In addition, molecular mechanisms involved in adenosine receptor desensitization are discussed.

Keywords Adenosine receptors $\cdot \beta$-arrestins · Caveolae . Desensitization $\cdot G$ protein-coupled receptor kinase $\cdot$ Lipid rafts · Internalization · Palmitoylation · Phosphorylation

\begin{tabular}{|c|c|}
\hline \multicolumn{2}{|c|}{ Abbreviations } \\
\hline $\mathrm{A}_{1} \mathrm{R}$ & adenosine $A_{1}$ receptor \\
\hline $\mathrm{A}_{2 \mathrm{~A}} \mathrm{R}$ & adenosine $A_{2 A}$ receptor \\
\hline $\mathrm{A}_{2 \mathrm{~B}} \mathrm{R}$ & adenosine $A_{2 B}$ receptor \\
\hline $\mathrm{A}_{3} \mathrm{R}$ & adenosine $A_{3}$ receptor \\
\hline ADA & adenosine deaminase \\
\hline ARNO & Arf nucleotide site opener \\
\hline$\beta_{1}-\mathrm{AR}$ & $\beta_{1}$ adrenergic receptor \\
\hline CADO & 2-chloroadenosine \\
\hline CGS21680 & $\begin{array}{l}\text { 2-[4-(2-carboxyethyl)phenethylamino]-5'-N- } \\
\text { ethylcarboxamidoadenosine }\end{array}$ \\
\hline$\left[{ }^{3} \mathrm{H}\right] \mathrm{CHA}$ & {$\left[{ }^{3} \mathrm{H}\right] N^{6}$-cyclohexyladenosine } \\
\hline Cl-IB- & 2-chloro- $N^{6}-\left(3\right.$-iodobenzyl)adenosine- $5^{\prime}-N$ - \\
\hline MECA & methyluronamide \\
\hline $\mathrm{CSC}$ & 8-(3-chlorostyryl)caffeine \\
\hline $\mathrm{D}_{1} \mathrm{R}$ & dopamine $\mathrm{D}_{1}$ receptor \\
\hline DPCPX & 8-cyclopentyl-1,3-dipropylxanthine \\
\hline $\begin{array}{l}\text { GIRK } \\
\text { channels }\end{array}$ & $\begin{array}{l}\mathrm{G} \text { protein-activated inwardly rectifying } \mathrm{K}^{+} \\
\text {channels }\end{array}$ \\
\hline GRK & G protein-coupled receptor kinase \\
\hline GPCR & G protein-coupled receptor \\
\hline $\begin{array}{l}2 \mathrm{HE}- \\
\text { NECA }\end{array}$ & 2-hexynyl-5'- $N$-ethylcarboxamidoadenosine \\
\hline
\end{tabular}




\begin{tabular}{|c|c|}
\hline 5-HT & serotonin, 5-hydroxytryptamine \\
\hline IB-MECA & $\begin{array}{l}N^{6} \text {-(3-iodobenzyl)adenosine- } 5^{\prime}-N- \\
\text { methyluronamide }\end{array}$ \\
\hline MRS 1523 & $\begin{array}{l}\text { 3-propyl-6-ethyl-5-[(ethylthio)carbonyl]-2 } \\
\text { phenyl-4-propyl-3-pyridine carboxylate }\end{array}$ \\
\hline MRS 1706 & $\begin{array}{l}N \text {-(4-acetylphenyl)-2-[4-(2,3,6,7-tetrahydro- } \\
\text { 2,6-dioxo-1,3-dipropyl-1H-purin- } \\
\text { 8-yl)phenoxy]acetamide }\end{array}$ \\
\hline NECA & 5 '- $N$-ethylcarboxamidoadenosine \\
\hline PKA & protein kinase A \\
\hline -PIA & R- $N^{6}$-phenylisopropyl adenosine \\
\hline M & (4-(2-[7-amino-2-(2-furyl $\{1,2,4\}$-triazolo \\
\hline 241385 & $\{2,3-\mathrm{a}\{1,3,5\}$ triazin-5-yl-aminoethyl)phenol \\
\hline
\end{tabular}

\section{Introduction}

Adenosine is an important neuromodulator involved in a variety of brain activities and it also serves many different functions in the periphery. This nucleoside, when extracellular, exerts its action via specific $G$ protein-coupled receptors (GPCRs) of the P1 class, divided into four subtypes: $A_{1} R, A_{2 A} R, A_{2 B} R$ and $A_{3} R$ [1]. GPCRs consist of a single polypeptide, containing seven $\alpha$-helices which are oriented perpendicular to the membrane. The $\mathrm{N}$ terminus is located at the extracellular side of the cell and often contains one or more glycosylation sites. The C terminus is located intracellularly and contains phosphorylation and palmitoylation sites, which are involved in regulation of receptor desensitization and internalization [2]. All adenosine receptors, with the exception of the $\mathrm{A}_{2 \mathrm{~A}} \mathrm{R}$, contain a palmitoylation site near the $\mathrm{C}$ terminus. The $\mathrm{A}_{2 \mathrm{~A}} \mathrm{R}$ is the only subtype with an extraordinary long $\mathrm{C}$ terminus, 122 amino acids versus 36 amino acids in e.g. the $A_{1} R$ [3]. All the adenosine receptors are glycosylated on the second extracellular loop, although glycosylation does not appear to influence ligand binding. The third intracellular loop and/or the $\mathrm{C}$ terminus are involved in coupling the adenosine receptors to $G$ proteins. Phosphorylation of in particular intracellular loop 3 is involved in desensitization and internalization of adenosine receptors [4-6].

Adenosine and analogues

Adenosine, consisting of a purine ring connected to a ribose group, is the endogenous ligand for the adenosine receptors (Fig. 1). Under normal conditions, adenosine is continuously formed extracellularly by dephosphorylation of ATP, ADP and/or AMP to adenosine by NTPDases (ectonucleoside triphosphate diphosphohydrolases). However, the $\mathrm{A}_{3} \mathrm{R}$ can also be activated by inosine, a breakdown product from adenosine [5]. Most adenosine receptor agonists are

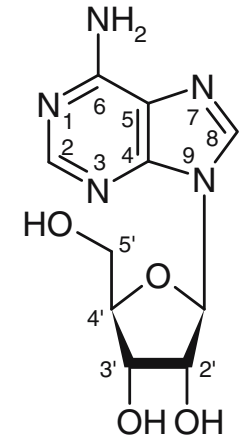<smiles>Cn1c(=O)c2c(ncn2C)n(C)c1=O</smiles>

Caffeine

\section{Adenosine}

Fig. 1 Chemical structures of the endogenous ligand adenosine and the antagonist caffeine

analogues of adenosine, modified by $\mathrm{N}^{6}, \mathrm{C} 2$ and $\mathrm{C} 8$ substitutions at the adenine base, and $\mathrm{C}^{\prime}$ modifications of the ribose moiety [5, 6]. Antagonists lack the ribose group and usually possess a mono-, bi- or tricyclic core structure, e.g. caffeine, which contains a xanthine as basic structure (Fig. 1). For extended reviews on high affinity agonists and antagonists for adenosine receptors and their structureactivity relationships, see Palmer and Stiles [1], Fredholm et al. [5], Jacobson and Gao [7], Beukers et al. [8], Müller [9] and Klotz [10].

Occurrence and physiological functions of adenosine receptors

The adenosine receptors are widespread throughout the body and exert many different functions both in the CNS and in the periphery.

The $A_{1} R$ is particularly prevalent in the central nervous system, with high levels in the cerebral cortex, hippocampus, cerebellum, thalamus, brain stem and spinal cord. Numerous peripheral tissues also express the $A_{1} R$, including vas deferens, testis, white adipose tissue, stomach, spleen, pituitary, adrenal gland, heart, aorta, liver, eye and bladder. Low levels are found in the lung, kidney and small intestine $[1,5,6]$. The $A_{1} R$ is involved in cardiovascular effects (e.g. reducing heart rate), inhibition of lipolysis and stimulation of glucose uptake in white adipocytes and the modulation of neurotransmitter release in the CNS [1]. The $\mathrm{A}_{1} \mathrm{R}$ also plays a role in anxiety, hyperalgesia, bronchoconstriction and the glomerular filtration rate and renin release in the kidney $[5,6,11]$.

In the CNS, the $\mathrm{A}_{2 \mathrm{~A}} \mathrm{R}$ is highly expressed in the striatum and olfactory tubercle [1]. In the periphery, it is highly expressed in the spleen, thymus, leucocytes and blood platelets, and intermediate levels are found in the heart, lung and blood vessels $[5,6]$. The $\mathrm{A}_{2 \mathrm{~A}} \mathrm{R}$ is involved in the onset of vasodilation, inhibition of platelet aggregation, exploratory activity, aggressiveness and hypoalgesia [1]. In addition, $\mathrm{A}_{2 \mathrm{~A}} \mathrm{R}$ plays a role in Parkinson's disease, 
Huntington's disease, Alzheimer's disease, ischaemia, attenuation of inflammation and neuroprotection, particularly in peripheral tissues $[5,6] . \mathrm{A}_{2 \mathrm{~A}}$ receptor antagonists slow the neurodegeneration which occurs in Parkinson's and Huntington's disease and also prevent toxicity induced by beta-amyloid in the development of Alzheimer's disease [12-14].

The $\mathrm{A}_{2 \mathrm{~B}} \mathrm{R}$ is widely expressed in the brain, but generally at very low levels. In the periphery, high levels of $A_{2 B} R$ were detected in the caecum, large intestine and urinary bladder. Lower levels were observed in the lung, spinal cord, vas deferens, pituitary, adipose tissue, adrenal gland, kidney, liver and ovaries $[5,6]$. Since there is a lack of specific agonists for the $A_{2 B} R$, little is known about the functional significance of this receptor. However, the $A_{2 B} R$ plays a role in mediating vasodilation in a.o. the aorta, the renal artery and the coronary artery of different species. It is also involved in allergic and inflammatory disorders $[5,6]$.

The $A_{3} R$ is expressed in the CNS, but at relatively low levels, and only the hypothalamus and the thalamus have been reported to contain $A_{3} R$ [15]. The highest levels of adenosine $A_{3} R$ have been found in the lung and liver, and somewhat lower levels were found in the aorta [1]. In addition, the $\mathrm{A}_{3} \mathrm{R}$ was found in eosinophils, mast cells, testis, kidney, placenta, heart, spleen, uterus, bladder, jejunum, aorta, proximal colon and eye, although with pronounced differences in expression level between species $[5,6,16]$. The $A_{3} R$ has been implicated in mediating allergic responses, airway inflammation and apoptotic events; however, the latter is dependent on the cell type involved and/or the type of activation $[5,16]$. Furthermore, the $A_{3} R$ is involved in the control of the cell cycle and inhibition of tumour growth both in vitro and in vivo [6]. In fact, adenosine $A_{3}$ receptors have been demonstrated to be more highly expressed in tumours than in healthy cells, suggesting a role for $A_{3} R$ as a tumour marker [17].

\section{Signal transduction of adenosine receptors}

G protein-coupling and second messengers

Heterotrimeric $\mathrm{G}$ proteins are guanine-nucleotide regulatory protein complexes composed of $\alpha$ and $\beta \gamma$ subunits. They are responsible for transmitting signals from $G$ proteincoupled receptors to effectors, e.g. adenylyl cyclase. Until now, $16 \alpha, 5 \beta$ and $14 \gamma$ isoforms have been reported [18]. $\mathrm{G}$ proteins are divided into several subclasses with a specific activity profile: $G_{s}$ proteins stimulate adenylyl cyclase, $G_{i}$ proteins inhibit adenylyl cyclase and stimulate GIRK channels, $G_{0}$ proteins stimulate $\mathrm{K}^{+}$ion channels, $\mathrm{G}_{\mathrm{q} / 11}$ proteins activate phospholipase $\mathrm{C}, \mathrm{G}_{12}$ proteins activate Rho guanine-nucleotide exchange factors (GEFs) and the olfac- tory $\mathrm{G}$ protein, $\mathrm{G}_{\mathrm{olf}}$, stimulates adenylyl cyclase. Upon receptor activation, both the $\alpha$ subunit and the $\beta \gamma$ subunit can signal, but to different effectors [19-21]. For a recent review on G proteins, see Milligan and Kostenis [18].

The $A_{1} R$ is usually coupled to a pertussis toxin-sensitive $\mathrm{G}_{\mathrm{i} \alpha}$ protein, which mediates inhibition of adenylyl cyclase and regulates calcium and potassium channels $[1,3,5,6$, 11]. Both the third intracellular loop and the C-terminal tail of the $A_{1} R$ are involved in $G_{i \alpha}$ coupling [5]. In addition, it has been reported that under certain conditions the $A_{1} R$ couples to $G_{s}$ to stimulate adenylyl cyclase, or to $G_{q / 11}$ to stimulate inositol phosphate production. Apparently, the specific activity state of the receptor or the nature of the agonist determine which $G$ protein class is activated by the $A_{1} R[22,23]$. The $A_{2 A} R$ in the periphery is coupled to cholera toxin-sensitive $\mathrm{G}_{\mathrm{s} \alpha}$ proteins, which increase adenylyl cyclase activity upon receptor activation. The $A_{2 A} R$ in the striatum is presumably coupled to $G_{\text {olf }}[5,6]$. The third intracellular loop, but not the $\mathrm{C}$ terminus of the $A_{2 A} R$, is involved in $G_{s \alpha}$ coupling [5]. The $A_{2 B} R$ is coupled to $\mathrm{G}_{\mathrm{s} \alpha}$ proteins leading to stimulation of adenylyl cyclase upon receptor activation [6]. There is quite some evidence that $A_{2 B} R$ can activate phospholipase $C$ as well, via $G_{q / 11}$ proteins [5]. The $A_{3} R$ is coupled to pertussis toxin-sensitive $\mathrm{G}_{\mathrm{i} \alpha}$ proteins, which mediate inhibition of adenylyl cyclase. In addition, $A_{3} R$ can stimulate phospholipase $C$ via $G_{q / 11}$ proteins $[5,6]$. For an extensive overview of adenosine receptor-G protein coupling, see Fredholm et al. [24].

\section{Desensitization and internalization-general principles and players}

Mechanisms to dampen GPCR signalling exist at every level in the cell. In this section attention will be paid to the underlying principles of desensitization and internalization and the protein partners involved in these processes.

\section{Receptor localization}

Depending on the localization signal, GPCRs in the plasma membrane can be targeted to lipid rafts $^{1}$ or caveolae ${ }^{2}$.

\footnotetext{
${ }^{1}$ Lipid rafts are planar domains of $25-100 \mathrm{~nm}$ in cell membranes enriched in specific lipids and proteins. They are in particular characterised by a high cholesterol and glycosphingolipid content in the outer leaflet of the lipid bilayer that gives them a gel-like liquidordered organization in comparison with the surrounding phospholipidrich disordered membrane [26].

${ }^{2}$ Caveolae are flask-shaped invaginations located at or near the plasma membrane with a $50-100 \mathrm{~nm}$ diameter. They are considered to be a non-planar subfamily of lipid rafts. The shape and structural organization of caveolae are due to the presence of caveolin-1, -2 and -3 , which self-assemble in high-mass oligomers to form a cytoplasmic coat on the membrane invaginations $[25,26]$.
} 
Fig. 2 Homologous (a) and heterologous (b) desensitization and subsequent internalization of GPCRs. $\alpha=\mathrm{G}_{\mathrm{i} \alpha}$, subunit, $\beta \gamma=\mathrm{G}_{\mathrm{i} \beta \gamma}$ subunit, $L$ ligand, $G R K \mathrm{G}$ protein-coupled receptor kinase, $P$ phosphorylated amino acids, $\beta$-arr $\beta$-arrestin, AP2 adaptin, $E$ effector, second messenger, $P K A$ protein kinase $\mathrm{A}, P K C$ protein kinase $\mathrm{C}$
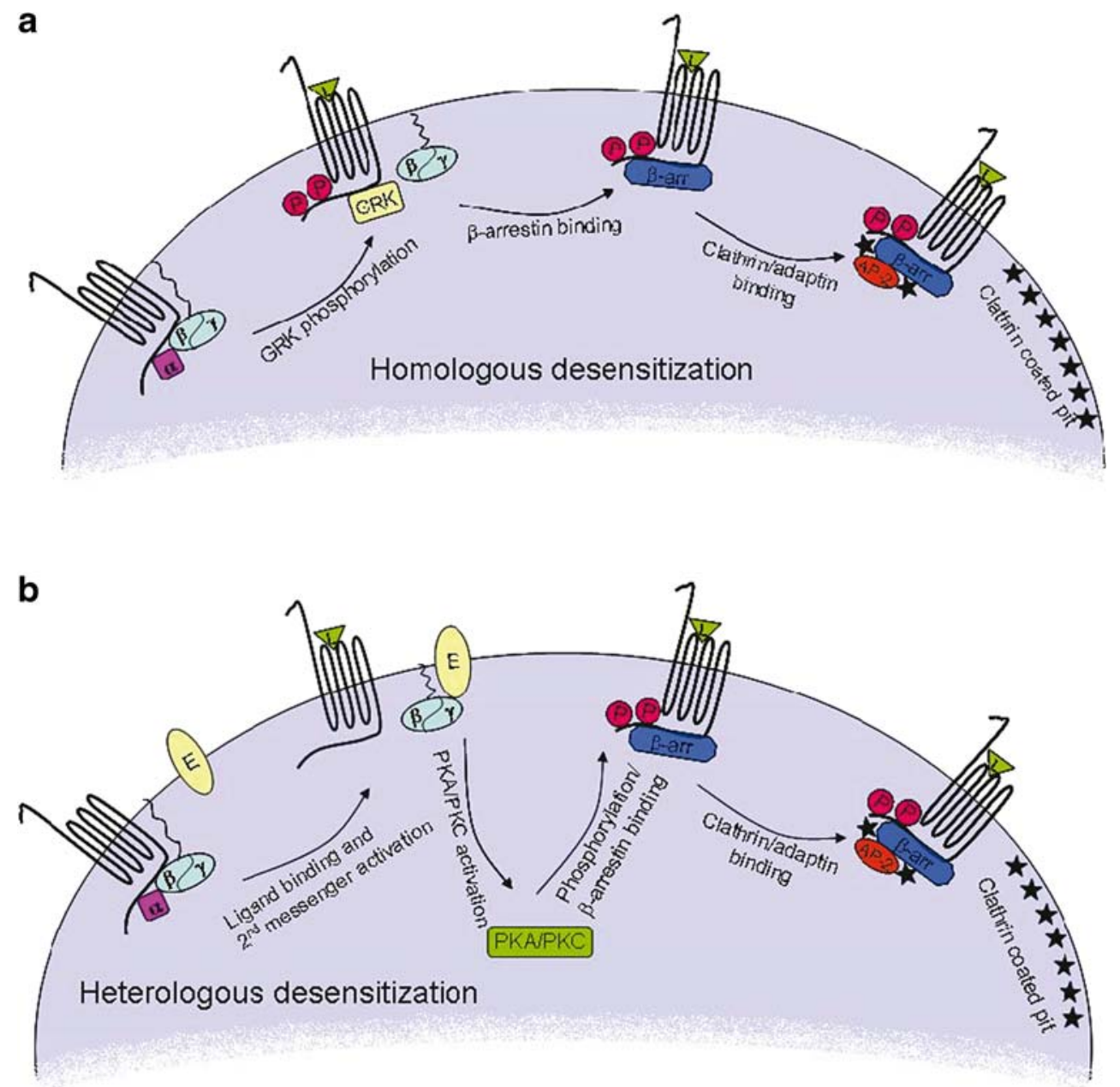

Different regions of GPCRs can influence not only the targeting to either lipid rafts or caveolae but may also enable an interaction of the receptor with constituents of these rafts and caveolae. For instance the extracellular part of the receptor might interact with GM1 gangliosides (glycosphingolipids) present in lipid rafts/caveolae. In addition, the C-terminal fatty acid acylation or palmitoylation may also affect targeting of GPCRs to either lipid rafts or caveolae. Finally, transmembrane regions may interact with cholesterol in the lipid rafts resulting in a change in conformation of the $\alpha$-helices. Since the conformation of $\alpha$-helices depends on the activation state of GPCRs, it may well be that agonist binding to the receptor may affect its localization in lipid rafts by means of molecular transitions leading to receptor activation $[25,26]$.

\section{Desensitization}

Desensitization reduces receptor activity and plays a role in signal duration, intensity and quality. Desensitization is initiated by phosphorylation of serine and/or threonine residues in the third intracellular loop and $\mathrm{C}$ terminus of the receptor. Two types of desensitization occur, heterologous and homologous desensitization, and both are the result of receptor phosphorylation. Heterologous desensitization is induced by phosphorylation of the receptor by protein kinase $\mathrm{A}$ or $\mathrm{C}$ - sometimes even without agonist occupancy. On the other hand, homologous desensitization is specific for agonist-occupied receptors and consists in most cases of two steps. First, the receptor is phosphorylated by one of the G protein-coupled receptor kinases (GRKs 1-7); then it binds to $\beta$-arrestin, of which two subtypes exist, which exhibit high affinity for agonist-occupied, phosphorylated receptors. $\beta$-Arrestin serves to sterically inhibit $G$ protein coupling, thereby terminating the $G$ protein activation, and may also target the receptor to clathrin-coated pits $^{3}$ for internalization (Fig. 2) [19, 25, 27, 28].

\footnotetext{
${ }^{3}$ Clathrin-coated pit is a specialized region of the cell surface that mediates the internalization of extracellular macromolecules and GPCRs. Coated pits derive their name from the presence of a distinctive polygonal lattice that decorates the inner surface of the membrane. This lattice is composed of multiple triskelion-shaped subunits that contain three clathrin heavy chains $(180 \mathrm{kD})$ and three clathrin light chains $(30-40 \mathrm{kD})$ plus a family of associated proteins with molecular sizes of $50 \mathrm{kD}$ and $110 \mathrm{kD}[29,30]$.
} 


\section{Internalization}

Receptor desensitization, initiated by phosphorylation of the receptor by different protein kinases (A or C) or GRKs, can be subsequently followed by receptor internalization. Upon phosphorylation, $\beta$-arrestin 1 or 2 is attracted to the receptor [31]. $\beta$-Arrestins not only interact with the phosphorylated receptor, but also bind to the heavy chain of clathrin, to the $\beta 2$-adaptin subunit of the clathrin adaptor protein AP2, and to phosphoinositides. These interactions direct the phosphorylated receptor to punctate clathrincoated pits in the cell membrane, which are internalized by action of the GTPase dynamin. Upon internalization, receptors can either be rapidly recycled to the plasma membrane, targeted to larger endosomes and slowly recycled, or degraded in lysosomes. The final destination of the internalized receptors largely depends on the $\beta$ arrestin subtype ( 1 or 2 ) that is recruited by the receptor upon phosphorylation and the duration of $\beta$-arrestin binding. In this way, internalization may regulate receptor resensitization and contributes to a positive regulation of receptor signalling $[19,25,31]$.

\section{Internalization pathways}

From internalization studies with several receptors, it appears that the internalization pathway is specific for receptor type, cell type, metabolic state of the cell, cellspecific factors etc. Receptor trafficking can be regulated in different ways (Fig. 3): (a) the receptor resides mainly in lipid rafts/caveolae and enters the cell via this pathway by default; (b) the receptor is in lipid rafts, but leaves these upon agonist binding to be internalized via clathrin-coated pits; (c) the receptor moves into lipid rafts upon agonist binding and is internalized via this pathway; (d) the receptor moves into lipid rafts after agonist binding to activate certain signalling events, but is eventually moved out of the lipid rafts to be internalized via clathrin-coated pits. Internalization can even be achieved via uncoated vesicles or by a combination of two or more of the aforementioned pathways. For example, $\beta 1-A R$ is internalized via both lipid rafts and clathrin-coated pits. PKA phosphorylation directs $\beta 1-\mathrm{AR}$ to a clathrin-coated pit, whereas GRK phosphorylation directs the receptor to lipid raft-mediated internalization [19, 25, 26].

\section{Function of lipid rafts/caveolae}

The existence of lipid rafts/caveolae serves different functions. First of all, lipid rafts act as 'stations' in which GPCRs accomplish specific signalling tasks by meeting a selected set of signalling molecules, e.g. G proteins and adenylyl cyclases. Another possible function of lipid rafts is the protection of receptors from rapid constitutive or agonist-induced internalization, thus allowing their coupling to specific signalling pathways. In addition, caveolin may regulate the constitutive activity of receptors [32]. Finally, the endocytic pathways that GPCRs choose may
Fig. 3 Different internalization pathways, adapted from Chini and Parenti, 2004 [25]. Internalization via (a) lipid rafts/caveolae, $(b)$ upon agonist binding, the receptor moves to clathrin-coated pits to be internalized, $(c)$ the receptor moves into lipid rafts upon agonist binding and is internalized, $(d)$ the receptor moves into lipid rafts upon agonist binding to activate certain signalling events, but is eventually moved out to be internalized via clathrin-coated pits. Ligand ( $L$, green triangle), clathrin-coated pits (dotted blue lines) and lipid rafts (solid pink lines) are indicated

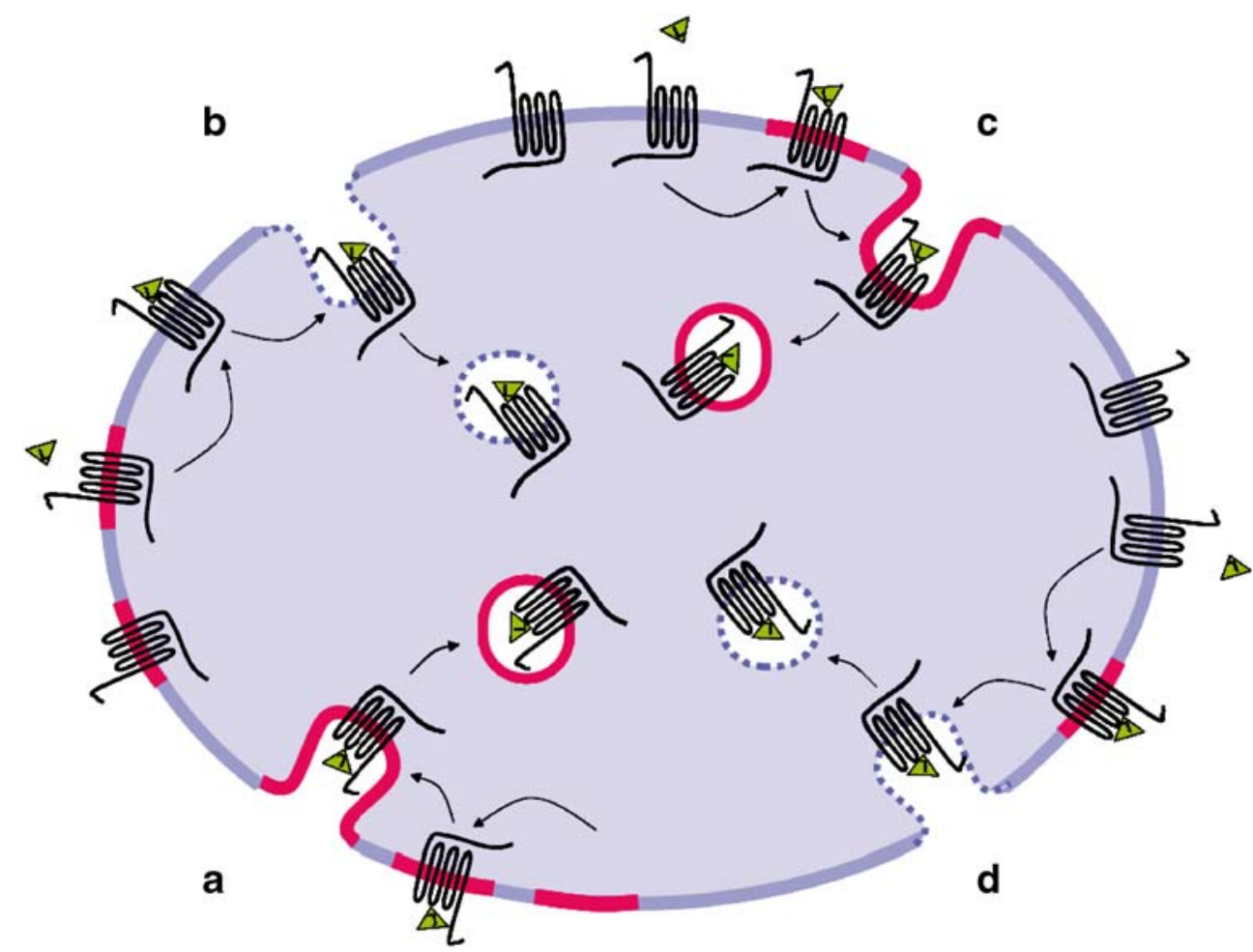


depend on cell-specific factors. Switching the internalization pathway from lipid rafts/caveolae to clathrin-coated pits may alter the final receptor destination $[19,25,26]$. Research on adenosine receptors probably provided the first account of receptor internalization via caveolae and lipid rafts, as an alternative to the well-described $\beta$-arrestin pathway [33].

\section{G protein-coupled receptor kinases (GRKs)}

Upon agonist binding to GPCRs, not only $\mathrm{G}$ proteins are recruited to the activated receptor conformation, but also two other protein families, namely the $G$ protein-coupled receptor kinases (GRKs) and the $\beta$-arrestins [31]. The GRK family consists of seven different genes. The GRKs have been divided into three protein subfamilies, based on sequence similarity. GRK1 and GRK7 belong together. The second subfamily consists of GRK2 and GRK3 since their membrane recruitment depends on interaction with $\mathrm{G} \beta \gamma$ subunits and phosphatidylinositol 4,5-bisphosphate. GRK2 and GRK3 are primarily responsible for agonistdependent receptor phosphorylation, $\beta$-arrestin recruitment and functional uncoupling of the receptor. GRK4, GRK5 and GRK6 form the third subfamily and are constitutively associated with the membrane. GRK1 and GRK7 are expressed mainly in the retinal rods and cones, whereas GRK4 expression is limited to the cerebellum, testis and kidney. In contrast, GRK2, GRK3, GRK5 and GRK6 are widely expressed in mammalian tissues [31].

\section{$\beta$-Arrestins}

$\beta$-Arrestins belong to the arrestin family of which four members have been identified. Arrestin 1 and arrestin 4 are expressed in the visual system in retinal photoreceptor cells; arrestin 2 (also called $\beta$-arrestin 1) and arrestin 3 (also called $\beta$-arrestin 2) are more widely expressed and are involved in the regulation of nonvisual GPCRs. The $\beta$ arrestins were originally discovered as molecules that bind to and desensitize the activated and phosphorylated form of $\mathrm{G}$ protein-coupled receptors as described before $[19,25,27$, $28,31]$. The $\beta$-arrestin protein consists of an $\mathrm{N}$ and a $\mathrm{C}$ domain, which are almost entirely composed of antiparallel $\beta$ sheets, connected by a linker of 12 amino acids. A 'polar core' is embedded between those two domains, and its disruption by the phosphorylated $\mathrm{C}$ terminus of the activated receptor leads to conformational changes in the $\beta$-arrestin. The $C$ tail of the $\beta$-arrestin is then released, exposing both the clathrin and the AP2 binding domains. Recently, it appeared that $\beta$-arrestins not only are involved in the desensitization of $\mathrm{G}$ protein-coupled receptors, but also act as signal transducers on their own. As a consequence, they emerge as multifunctional adaptor/ scaffold proteins which mediate cellular processes such as chemotaxis, apoptosis and metastasis besides receptor signalling and trafficking. For an extensive and recent review on the interactions of $\beta$-arrestins with other cellular proteins, see Lefkowitz et al. [34].

GRKs and $\beta$-arrestins orchestrate GPCR activities at three different levels: (1) silencing: the functional uncoupling of the receptor from its $G$ protein by a mechanism known as 'homologous desensitization', (2) trafficking, which involves receptor internalization, resensitization and/ or degradation, and (3) cross-signalling: activation or inhibition of intracellular signalling pathways, independent of heterotrimeric $\mathrm{G}$ proteins [31].

\section{Dampening adenosine receptor signals}

In this section we will discuss the evidence for and mechanisms of desensitization and internalization of the four adenosine receptor subtypes. For each receptor we will first summarize results from in vitro, ex vivo and in vivo studies. This will be followed by a more biochemical approach in which we will focus on the molecular mechanisms of adenosine receptor desensitization and internalization by paying attention to the role of accessory proteins, the influence of receptor mutations, etc. We will refer to earlier seminal publications, but mostly focus on more recent evidence for adenosine receptor desensitization and internalization.

\section{$A_{1}$ receptor}

\section{Cellular and physiological studies}

The early evidence for adenosine $A_{1}$ receptor desensitization was largely obtained from primary cells, cell lines, tissues or tissue slices, and intact animals that were exposed to varying concentrations of adenosine receptor agonists (either $\mathrm{A}_{1}$-selective or not), often examined over several time periods.

Stiles and co-workers were among the first to study $\mathrm{A}_{1}$ receptor desensitization in detail (1991). Ramkumar et al. pretreated DDT1 MF-2 cells, a smooth muscle cell line expressing both $A_{1}$ and $A_{2 A}$ receptors, with R-phenylisopropyl adenosine (R-PIA) for up to $24 \mathrm{~h}$, after which the adenylyl cyclase activity was reduced by approximately $50 \%$. This was associated with a significant decrease in cell membrane-bound $\mathrm{A}_{1}$ receptors and a concomitant increase of receptor number in intracellular compartments. The authors also showed an increase in receptor phosphorylation, nicely paralleling the time course of adenylyl cyclase modulation [35]. In a later study, Nie et al. reported similar 
findings in the same cell line, although desensitization occurred at a somewhat faster pace (4 h) [36]. Interestingly, Palmer et al. were unable to demonstrate desensitization in $\mathrm{CHO}$ cells expressing the human $\mathrm{A}_{1} \mathrm{R}$ [37]. Klaasse et al., however, were able to show internalization of the human $\mathrm{A}_{1} \mathrm{R}$ tagged with a $\mathrm{C}$-terminal yellow fluorescent protein (hA $\mathrm{A}_{1}$ YFP-R), stably expressed in CHO cells. Exposure of these cells for $16 \mathrm{~h}$ to $400 \mathrm{nM}$ or $4 \mu \mathrm{M}$ CPA resulted in 25 and $40 \%$ receptor internalization, respectively. Addition of $10 \mu \mathrm{M}$ of the allosteric enhancer PD81,723 did not accelerate the internalization process, but lowered the threshold concentration at which internalization occurred. Under those conditions a small degree of internalization was observed already at a concentration of $40 \mathrm{nM} \mathrm{CPA}$, and at $400 \mathrm{nM} \mathrm{CPA}, 59 \%$ of the receptors internalized [38].

Exposure of cerebellar granule cells, endogenously expressing $\mathrm{A}_{1} \mathrm{R}$, to $100 \mathrm{nM}$ R-PIA for $2-48 \mathrm{~h}$ led to a blunting of the inhibition of adenylyl cyclase. Along with this observation, a decrease of $\left[{ }^{3} \mathrm{H}\right]$ cyclohexyladenosine $\left(\left[{ }^{3} \mathrm{H}\right] \mathrm{CHA}\right)$ binding to intact cerebellar granule cells and an increase of $\left[{ }^{3} \mathrm{H}\right] \mathrm{CHA}$ binding in microsomes was detected. Simultaneously, a decrease in the steady-state level of $\mathrm{G}_{\mathrm{i} \alpha}$ in plasma membrane and microsomes was observed. These findings point not only to homologous desensitization, but also to subsequent internalization of the $A_{1} R$ in the microsomal fraction of cerebellar granule cells upon longterm agonist exposure. However, no change in mRNA level was observed, suggesting that post-transcriptional regulation underlies receptor desensitization [39].

In hippocampal neurons, $A_{1} R s$ are present on both presynaptic and postsynaptic terminals, as well as on the cell body and dendrites where they exert different actions. To address the question of whether desensitization was influenced by subcellular localization, neurons were exposed to the agonist 2-chloroadenosine (CADO, $20 \mu \mathrm{M}$ ) from 2 up to $96 \mathrm{~h}$. It was found that upon agonist exposure in cultured hippocampal neurons, the presynaptic $A_{1} R s$ desensitize less quickly $\left(>12 \mathrm{~h}\right.$ ) than the postsynaptic $\mathrm{A}_{1} \mathrm{Rs}$ $(2 \mathrm{~h})$. In accordance, the recovery of desensitized presynaptic $\mathrm{A}_{1} \mathrm{Rs}$ also requires more time $(48 \mathrm{~h}$ vs $8 \mathrm{~h}$ for postsynaptic $\left.A_{1} R\right)$. Desensitization of the postsynaptic $A_{1}$ Rs apparently occurs at the level of the receptor, because the other elements of the signal transduction machinery appeared to be fully functional upon receptor desensitization. All in all, these results suggest that the extent and the kinetics of agonist-induced desensitization of $\mathrm{A}_{1}$ Rs depend on the subcellular localization of the receptors [40].

Using a more intact preparation, Coelho et al. found that the density of $\mathrm{A}_{1} \mathrm{R}$ in rat hippocampal slices was decreased by $30 \%$ upon $60 \mathrm{~min}$ of imposed hypoxia. This desensitization could be mimicked by adding the $\mathrm{A}_{1} \mathrm{R}$ agonist CADO $(10 \mu \mathrm{M})$ for $60 \mathrm{~min}$ and was prevented by adding the $A_{1} R$ antagonist DPCPX. These results suggest that hypoxia leads to an increase in extracellular adenosine levels, and a subsequent, quite rapid $(<90 \mathrm{~min})$ desensitization, possibly followed by subsequent internalization of the $A_{1} R$ in nerve terminals [41].

Rat in vivo studies also demonstrated $A_{1} R$ desensitization. In a study by Parsons and Stiles rats were chronically (6 days) infused with R-PIA. Examination of adipocyte membranes of both treated and control rats revealed a $40 \%$ lower inhibition of adenylyl cyclase in the treated animals, coinciding with a reduced number of $\mathrm{A}_{1} \mathrm{Rs}(68 \%$ agonistoccupied receptors remaining) as determined by radioligand binding [42]. Upon further study it was noticed that the effects on adenylyl cyclase were not $A_{1} R$ specific but were controlled at the level of adipocyte $G$ proteins. $G_{i}$ levels appeared downregulated, whereas the amount of $G_{s}$ in the preparation was increased, although not at the level of their mRNA, suggesting a heterologous form of desensitization [43].

Chronic exposure of rats to R-PIA (6 days) also led to $A_{1} R$ desensitization in the brain, and subsequent reduced inhibition of adenylyl cyclase. This loss of response was accompanied by a significant decrease in both total numbers of $A_{1} R$ and $G_{i \alpha}$ proteins in synaptic plasma membranes in the brain, paralleling the finding by Stiles and co-workers in adipocytes [44]. As a consequence, a significant increase of $A_{1} R$ was observed in microsomes and coated vesicles, which suggested a role for coated vesicles in the internalization of $A_{1} R$. Similarly, chronic agonist exposure of rats to NECA (6 days) resulted in a significant decrease of $\mathrm{A}_{1} \mathrm{R}$ in the high-affinity state in the rat brain, however without changes in adenylyl cyclase activity or inhibition of the $\mathrm{G}_{\mathrm{i} \alpha}$ proteins [45].

\section{Molecular mechanisms}

As discussed in the general introduction to this review, receptor posttranslational modifications, receptor phosphorylation, recruitment of arrestins and the formation of clathrin-coated pits are elements of the molecular machinery of desensitization and internalization. In addition, other potential protein partners in the two processes have been studied for the various adenosine receptor subtypes, which will also be discussed.

Effect of receptor posttranslational modifications on desensitization and/or internalization

Gao et al. studied the effects of preventing palmitoylation of the $\mathrm{A}_{1} \mathrm{R}$. It appeared that the $\mathrm{Cys}^{309}$ Ala mutation, thus removing the palmitoylation site of the human $A_{1} R$, had no effect on internalization [46]. These findings were later confirmed by Ferguson et al. [47]. 
GRKs and arrestins

$\mathrm{A}_{1} \mathrm{R}$ phosphorylation by GRKs has been subject to debate. Palmer et al. and Ferguson et al. failed to demonstrate GRK-2 phosphorylation of $A_{1} R$; in the latter study it was found that nonphosphorylated $\mathrm{A}_{1} \mathrm{R}$ redistributes arrestin 3 from the cytoplasm into punctate clusters at the plasma membrane [37, 47]. Nie et al., however, reported that within $1 \mathrm{~h}$ of exposure of $\mathrm{DDT}_{1} \mathrm{MF}-2$ cells to R-PIA, rapid translocation of GRKs was observed from the cytosol to the cytoplasm [36]. In a further biochemical approach with both purified receptor and GRK-2, a phosphorylated receptor was obtained that showed enhanced affinity for arrestins over $\mathrm{G}$ proteins. The same receptor kinase, upon overexpression in FRTL-5 cells, influenced $\mathrm{A}_{1} \mathrm{R}$ signalling, however, not via $\mathrm{G}_{\mathrm{i} \alpha}$-mediated adenylyl cyclase but through $\mathrm{G}_{\mathrm{i} \beta \gamma}$-mediated MAP kinase activation [48]. It may be concluded that under physiological conditions $\mathrm{A}_{1} \mathrm{R}$ phosphorylation does not (readily) take place, which would be a rationale for the long time periods required for receptor internalization.

\section{Other protein partners}

The ectoenzyme adenosine deaminase (ADA) regulates the extracellular adenosine concentration by converting excess adenosine into inosine. However, ADA also plays a role in the desensitization and internalization of $\mathrm{A}_{1} \mathrm{R}$ in smooth muscle DDT ${ }_{1}$ MF-2 cells $[49,50]$ and LLC-PK $_{1}$ epithelial cells [51], acting as a receptor activity-modifying protein (RAMP). Upon agonist exposure (100 nM R-PIA, 2 h), $\mathrm{ADA}$ and $\mathrm{A}_{1} \mathrm{R}$ formed complexes on the cell surface, clustered and internalized together to intracellular compartments. Such clustering of adenosine $A_{1}$ receptors prior to internalization was also reported by Ciruela et al. and Saura et al. [49, 52]. The intracellular vesicles contained the lipid raft marker protein caveolin. Filipin, an agent that disrupts rafts or caveolae, inhibited $\mathrm{A}_{1} \mathrm{R}$ internalization. In contrast, acidic treatment disrupting clathrin-coated vesicles did not inhibit agonist-induced internalization of $A_{1} R$. These results indicate that $\mathrm{ADA}$ and $\mathrm{A}_{1} \mathrm{R}$ form a stable complex in the cell membrane of LLC-PK ${ }_{1}$ cells, internalizing upon agonist exposure via lipid rafts, in a clathrin-independent pathway. Furthermore, a direct interaction of the $\mathrm{C}$ terminus of $\mathrm{A}_{1} \mathrm{R}$ with caveolin was demonstrated [50]. These and other data suggest that the mode of receptor compartmentalization in response to agonist stimulation may be governed by both receptor subtype and cell type [51].

Another accessory protein, the heat shock cognate protein 73 (hsc73), a member of the hsp70 family, was identified as a cytosolic component able to interact with the third intracellular loop of the $\mathrm{A}_{1} \mathrm{R}$. The interaction between hsc73 (30 nM) and $A_{1} R$ led to a marked reduction in affinity of ligands for the $A_{1} R$ and also prevented activation of the $\mathrm{G}$ proteins, even more so than the addition of GTP analogues or GTP itself $(100 \mu \mathrm{M})$. These effects were completely prevented by the addition of $25 \mathrm{nM}$ ADA. A high percentage of $A_{1} R$ was coupled to hsc73 in cell lysate, according to immunoprecipitation experiments. A remarkable feature upon internalization of the receptor in $\mathrm{DDT}_{1} \mathrm{MF}-2$ cells was found; $A_{1} R s$ internalized via two different vesicle types, one in which $\mathrm{A}_{1} \mathrm{R}$ and $\mathrm{hsc} 73$ are colocalized and another in which hsc73 was absent. These observations open the possibility that signalling via GPCRs is regulated at least to some extent by heat shock proteins [53].

\section{Receptor-receptor interactions}

Dunwiddie et al. found that activation of $A_{3} R$ with a selective $\mathrm{A}_{3} \mathrm{R}$ agonist resulted in subsequent heterologous desensitization of the $A_{1} R$, as observed in electrophysiological experiments in the CA1 region of rat hippocampus. Similar results were obtained after $A_{3} R$ occupancy via a brief superfusion with a high concentration of adenosine [54].

Lopes et al. investigated how activated $\mathrm{A}_{2 \mathrm{~A}} \mathrm{R}$ influenced $\mathrm{A}_{1} \mathrm{R}$ function and whether this interaction was modified in aged rats. In hippocampal and cortical nerve terminals, the $\mathrm{A}_{2 \mathrm{~A}} \mathrm{R}$ agonist CGS $21680(30 \mathrm{nM})$ was able to lower the binding affinity of the $\mathrm{A}_{1} \mathrm{R}$-selective agonist CPA, and this was taken as proof for $A_{1} R$ desensitization. The effect was counteracted by the addition of the $\mathrm{A}_{2 \mathrm{~A}} \mathrm{R}$ antagonist $\mathrm{ZM}$ $241385(20 \mathrm{nM})$. This reduction in $\mathrm{A}_{1} \mathrm{R}$ function could only be detected in young adult rats ( 6 weeks), but not in old rats (24 months). The addition of a PKC inhibitor, chelerythrine (6 $\mu \mathrm{M})$, also prevented the desensitization of $A_{1} R$ [55]. Similarly, Ciruela et al. [56] demonstrated that $\mathrm{A}_{1} \mathrm{R}-\mathrm{A}_{2 \mathrm{~A}} \mathrm{R}$ heteromers were able to modulate the glutamatergic neurotransmission in the rat striatum. The main biochemical characteristic of this heteromer is the ability of the agonistoccupied $A_{2 A} R$ to reduce the agonist affinity of the $A_{1} R$ [56].

By binding to cannabinoid $\mathrm{CB}_{1}$ receptors in Purkinje fibers in the cerebellum, $\Delta^{9}$-tetrahydrocannabinol inhibits adenylyl cyclase and consequently motor coordination. Long-term $\Delta^{9}$-tetrahydrocannabinol treatment resulted in $\mathrm{CB}_{1} \mathrm{R}$ downregulation, desensitization of the $\mathrm{G}_{\mathrm{i} \alpha}$ protein and desensitization of adenylyl cyclase. G protein activation by $\mathrm{A}_{1} \mathrm{R}$, however, was unaffected. Surprisingly, heterologous attenuation of $\mathrm{A}_{1} \mathrm{R}$-mediated inhibition of adenylyl cyclase was observed. These results indicate that long-term $\Delta^{9}$-tetrahydrocannabinol administration produces a disruption of inhibitory receptor control of cerebellar adenylyl cyclase and suggest a potential mechanism of cross-tolerance to the motor effects of cannabinoid and $A_{1}$ agonists [57].

$D_{1} R$ and $A_{1} R$ have been shown to form functionally interacting heteromeric complexes in engineered cell lines 
and in cortical neurons in culture. Pretreatment with an $\mathrm{A}_{1} \mathrm{R}$ agonist caused complex formation of both receptors. Combined pretreatment with selective agonists for both receptors (but not one agonist alone) substantially reduced cAMP accumulation induced via the $D_{1} R$, indicative for this receptor's desensitization [58].

\section{$A_{2 A}$ receptor}

\section{Cellular and physiological studies}

$\mathrm{DDT}_{1}$ MF-2 cells, expressing both $\mathrm{A}_{1} \mathrm{R}$ and $\mathrm{A}_{2 \mathrm{~A}} \mathrm{R}$, were exposed to an $\mathrm{A}_{2 \mathrm{~A}}$-selective agonist, which resulted in a rapid loss $\left(t_{1 / 2}=45 \mathrm{~min}\right)$ of agonist-stimulated cAMP production in these cells. This receptor desensitization, however, did not involve a reduction in cell membrane receptor number or a change in ligand affinity [35].

Prolonged exposure of PC12 cells, expressing both $A_{2 A} R$ and $A_{2 B} R$, to $A R$ agonists led to a fast $(30 \mathrm{~min})$ and significant inhibition of $A_{2 A} R$ stimulation by the $A_{2 A} R$ selective agonist CGS21680. This effect appeared to occur at the level of adenylyl cyclase, since no change was observed in receptor number or in CGS21680's affinity for the receptor. This conclusion was corroborated by the finding of reduced activation of adenylyl cyclase by forskolin. Longer agonist exposure $(12-20 \mathrm{~h})$ led to a reduction of $\mathrm{G}_{\mathrm{s} \alpha}$ levels, whereas no changes occurred in the short-term protocol [59].

NG108-15 neuroblastoma $x$ glioma hybrid cells express both $A_{2 A} R$ and $A_{2 B} R[60,61]$. Treatment of the cells with the non-selective agonist NECA followed by its washout led to a rapid $\left(\mathrm{t}_{1 / 2}=20 \mathrm{~min}\right)$ and pronounced reduction in cAMP production by the $\mathrm{A}_{2 \mathrm{~A}} \mathrm{R}$-selective agonist CGS21680 when compared to vehicle-treated cells.

Palmer et al. [62] generated $\mathrm{CHO}$ cells solely expressing the recombinant (canine) $\mathrm{A}_{2 \mathrm{~A}} \mathrm{R}$ and examined the desensitization process of this receptor. Cells exposed to NECA showed a rapid desensitization of $\mathrm{A}_{2 \mathrm{~A}} \mathrm{R}$-stimulated adenylyl cyclase activity with no obvious difference between pretreatment of $30 \mathrm{~min}$ or $24 \mathrm{~h}$. This was associated with a slightly reduced affinity of the receptor for the $\mathrm{A}_{2 \mathrm{~A}} \mathrm{R}$-selective radiolabelled agonist $\left[{ }^{3} \mathrm{H}\right] \mathrm{CGS} 21680$. Cell surface receptor numbers only diminished significantly (up to $40 \%$ ) upon longer-term pretreatment $\left(\mathrm{t}_{1 / 2}=8 \mathrm{~h}\right)$ [62].

Using a tissue preparation, Conti et al. investigated whether prolonged exposure of $\mathrm{A}_{2 \mathrm{~A}} \mathrm{R}$ to the non-selective agonist NECA, or to the selective $\mathrm{A}_{2 \mathrm{~A}} \mathrm{R}$ agonists CGS21680 and 2HE-NECA, influenced $\mathrm{A}_{2 \mathrm{~A}} \mathrm{R}$ desensitization. The authors used the porcine coronary artery as a sensitive vascular model, expressing among others $\mathrm{A}_{2 \mathrm{~A}}$ Rs. The arteries were first precontracted by adding $3 \mu \mathrm{M}$ PGF $\alpha$. NECA, CGS21680 and 2HE-NECA showed high affinities for the $\mathrm{A}_{2 \mathrm{~A}} \mathrm{R}$ ( $\left(\mathrm{EC}_{50}\right.$ 's of 72,40 and $20 \mathrm{nM}$, respectively) inducing vasorelaxation. Next, coronary arteries were pretreated with $10 \mu \mathrm{M}$ NECA for $30 \mathrm{~min}$ or $2 \mathrm{~h}$. After a 2-h washout period, the functional response was assessed. It appeared that preincubation with NECA did not hamper the vasorelaxing effects of CGS21680 and 2HE-NECA. However, NECA response curves were shifted to the right after NECA pretreatment [63]. These results seem inconclusive, since NECA pretreatment might 'hit' other adenosine receptor subtypes.

$A_{2 A} R s$, next to $A_{1} R$, are present on presynaptic baroreceptor afferent terminals within the nucleus tractus solitarius (NTS) in the brain [64]. It was observed that these $\mathrm{A}_{2 \mathrm{~A}} \mathrm{R}$ modulate 5-HT release as a mechanism of baroreflex control mediated by the NTS. Low concentrations of the non-selective agonist NECA $(0.3-3 \mathrm{nM})$, briefly exposed ( $5 \mathrm{~min}$ ) to NTS brain slices, induced the release of 5-HT caused by the activation of the $\mathrm{A}_{2 \mathrm{~A}} \mathrm{R}$ present at presynaptic nerves. This effect could be blocked by the addition of the adenosine $\mathrm{A}_{2 \mathrm{~A}} \mathrm{R}$ antagonist 8-(3-chlorostyryl)caffeine $(\mathrm{CSC} ; 100 \mathrm{nM})$. Longer exposure of NECA $(20 \mathrm{~min})$ to the NTS slices resulted in inhibition of the 5-HT release, probably caused by quick desensitization of the $\mathrm{A}_{2 \mathrm{~A}} \mathrm{R}$ (15 min) and subsequent involvement of the $A_{1} R$ [65]. These findings were corroborated in a similar study with CGS21680, an $\mathrm{A}_{2 \mathrm{~A}} \mathrm{R}$-selective agonist [66].

The effects on AR fate upon chronic agonist exposure were studied in vivo in rat brain [45]. After 6 days of NECA treatment, the adenylyl cyclase activity in synaptic plasma membranes was decreased, suggesting a desensitization of $\mathrm{A}_{2} \mathrm{Rs}$, although the authors did not specify or study which $\mathrm{A}_{2} \mathrm{R}$ subtype was involved. $\mathrm{G}_{\mathrm{s}}$ protein levels were decreased indicating $G_{s}$ downregulation as the mechanism of desensitization.

Interestingly, Rekik and Mustafa [67] showed that chronic antagonist treatment (3 days) of porcine coronary arteries with ZM241,385 led to a decreased agonist responsiveness. Although $\mathrm{A}_{2 \mathrm{~A}}$ receptor expression went up, it appeared that the levels of $\mathrm{G}_{\mathrm{s}}$ had decreased, altogether leading to a functional desensitization of the relaxing response by e.g. CGS21680 [67]. It should be kept in mind that ZM241,385 is also a potent antagonist for the adenosine $\mathrm{A}_{2 \mathrm{~B}}$ receptor.

\section{Molecular mechanisms}

Effect of receptor $\mathrm{C}$ terminus on desensitization and/or internalization

To investigate the importance of the (120 amino acid residues) long $\mathrm{C}$ terminus of the $\mathrm{A}_{2 \mathrm{~A}} \mathrm{R}$ receptor in inducing desensitization and internalization, Palmer and Stiles 
introduced several mutations and deletions into the receptor tail. It appeared that deletion of the last 95 amino acids of the $\mathrm{C}$ terminus, containing 10 possible phosphorylation sites, did not have any effect on radioligand binding, adenylyl cyclase activity or desensitization kinetics compared to the wild-type $A_{2 A} R$. However, when two possible phosphorylation sites (Thr 298 and Ser 305) just upstream the 95 deleted amino acids were mutated to Ala, short-term (30 $\mathrm{min}$ ) agonist-induced desensitization was attenuated, while the long-term $(24 \mathrm{~h})$ desensitization was not affected. Single mutations revealed that mutation of Thr 298 alone was sufficient to reduce receptor phosphorylation and agonist-induced short-term desensitization. This study also shows that short-term and long-term desensitization have distinct structural requirements and do not occur via the same mechanism [4].

\section{GRKs and arrestins}

Which GRK isoforms are involved in the phosphorylation of the $A_{2 A} R$ is not entirely clear yet. However, a putative role for GRK2 and/or GRK5 has been suggested [4]. The role of GRK2 in agonist-induced phosphorylation and subsequent desensitization of $\mathrm{A}_{2 \mathrm{~A}} \mathrm{R}$ and $\mathrm{A}_{2 \mathrm{~B}} \mathrm{R}$ was thoroughly investigated by Kelly and co-workers. Wild-type GRK2 was stably expressed in NG108-15 cells, which endogenously express $A_{2 A} R$ and $A_{2 B} R$. The acute stimulation of adenylyl cyclase by activation of $\mathrm{A}_{2 \mathrm{~A}} \mathrm{R}$ was markedly reduced in NG108-15 cells overexpressing wildtype GRK2. This was probably caused by GRK2-dependent pre-desensitization of the $\mathrm{A}_{2 \mathrm{~A}} \mathrm{R}$ by extracellular adenosine. This effect could be reversed by pretreating the cells $24 \mathrm{~h}$ with $0.5 \mathrm{unit} / \mathrm{ml}$ ADA [68]. The same research group investigated the effect of a dominant-negative GRK2 mutant on the desensitization of the $\mathrm{A}_{2 \mathrm{~A}} \mathrm{R}$ [60]. Stable transfection of a GRK2Lys220Arg mutant in NG108-15 cells reduced desensitization of the $\mathrm{A}_{2 \mathrm{~A}} \mathrm{R}$ by $50 \%$ following a 30-min treatment with the adenosine agonist NECA.

Tumour necrosis factor (TNF)- $\alpha$ treatment of human monocytoid THP-1 cells expressing the $\mathrm{A}_{2 \mathrm{~A}} \mathrm{R}$ prevented desensitization of this receptor, occurring under control conditions upon pretreatment with CGS21680 or NECA [69]. It was discovered that the TNF- $\alpha$ treatment prevented GRK2 translocation to and decreased GRK2 association with the plasma membranes of these cells as a consequence of the activation of a sphingomyelinase-dependent pathway.

In another study, Mundell and Kelly investigated the effect of inhibitors of receptor internalization on desensitization and resensitization of ARs in NG108-15 cells [70]. Before agonist exposure, cells were pretreated with hypertonic sucrose or concanavalin A (ConA), both inhibitors of internalization. This pretreatment did not affect the agonistinduced desensitization of the $\mathrm{A}_{2 \mathrm{~A}} \mathrm{R}$. However, the resensi- tization of the $\mathrm{A}_{2 \mathrm{~A}} \mathrm{R}$ upon agonist removal was abolished in the presence of ConA or sucrose.

Arrestins 2 and 3 have been implicated in the downstream desensitization process. CGS21680 stimulation of a tagged $\mathrm{A}_{2 \mathrm{~A}} \mathrm{R}$ transiently transfected in HEK293 cells induced the translocation of GFP-tagged arrestins 2 and 3 towards the plasma membrane. A dominant-negative arrestin 2 mutant inhibited agonist-induced internalization [71].

\section{Other protein partners}

The long $\mathrm{C}$ terminus of the $\mathrm{A}_{2 \mathrm{~A}} \mathrm{R}$ has been coined a 'coincidence detector' as it recognizes quite a number of other proteins such as $\alpha$-actinin and ARNO, the Arf nucleotide site opener (for a review see Gsandtner and Freissmuth [72]). $\alpha$-Actinin may play a role in receptor internalization, not unlikely for a protein involved in cytoskeletal arrangements [71], however ARNO does not [73].

\section{Receptor-receptor interactions}

The $A_{2 A} R$ colocalizes with $D_{2}$ dopamine receptors in the basal ganglia, and their interaction has been documented on several occasions [74]. For instance, the protein-protein interaction between $\mathrm{A}_{2 \mathrm{~A}} \mathrm{R}-\mathrm{D}_{2} \mathrm{R}$ was confirmed in HEK293T cells. The most likely mode of interaction is that helix 5 and/or helix 6 and the N-terminal portion of $\mathrm{I} 3$ in the $\mathrm{D}_{2} \mathrm{R}$ approach helix 4 and the $\mathrm{C}$ terminus of the $\mathrm{A}_{2 \mathrm{~A}} \mathrm{R}$ [75]. Within the scope of this review fits the observation that activation of the $\mathrm{D}_{2}$ receptor actually sensitizes $\mathrm{A}_{2 \mathrm{~A}} \mathrm{R}$-mediated increases in cAMP production, in CHO cells expressing both receptors [76] as well as in CAD and NS20Y neuroblastoma cells in which the $\mathrm{D}_{2}$ receptor was expressed [77]. In SH-SY5Y neuroblastoma cells co-stimulation of $\mathrm{A}_{2 \mathrm{~A}} \mathrm{R}$ and $\mathrm{D}_{2} \mathrm{R}$ accelerated $\mathrm{D}_{2} \mathrm{R}$ desensitization, probably by causing or enhancing $\mathrm{D}_{2} \mathrm{R}$ internalization [78]. Recently it was found that in these SHSY5Y neuroblastoma cells the $A_{2 A} R$ also formed heteromers with the endogenously expressed $C_{1} R$. The $C_{1} R$ is negatively coupled to adenylyl cyclase and requires previous or simultaneous activation of $\mathrm{A}_{2 \mathrm{~A}} \mathrm{R}$ to signal in these cells [79].

\section{$\mathbf{A}_{2 \mathrm{~B}}$ receptor}

Cellular and physiological studies

The adenosine $A_{2 B}$ receptor $\left(A_{2 B} R\right)$ is endogenously expressed on most artificial cell lines, such as COS and HEK293 cells. The exception is formed by $\mathrm{CHO}$ cells that lack this adenosine receptor subtype. 
The $\mathrm{A}_{2 \mathrm{~B}} \mathrm{R}$, like the other three adenosine receptor subtypes, is subject to agonist-induced desensitization. This was measured on the level of cAMP production by Peters et al. [80]. Pretreatment of COS7 cells endogenously expressing $\mathrm{A}_{2 \mathrm{~B}}$ receptors with the non-selective agonist NECA $(1 \mu \mathrm{M})$ for 1 up to $17 \mathrm{~h}$ led to a significant reduction in cAMP production upon acute agonist challenge, already after $1 \mathrm{~h}$ of pretreatment. Maximal reduction of cAMP production was reached after $4 \mathrm{~h}$ of pretreatment. $\mathrm{CHO}$ cells stably expressing a $5^{\prime}$ FLAG epitope-tagged $\mathrm{A}_{2 \mathrm{~B}}$ receptor showed the same result, albeit that maximal reduction of cAMP response was already achieved after $1 \mathrm{~h}$ of pretreatment. Also mouse 3T3-L1 cells and human HEK293 cells, endogenously expressing the $A_{2 B} R$, showed a decreased cAMP response after $2 \mathrm{~h}$ and $5.5 \mathrm{~h}$ of pretreatment with $1 \mu \mathrm{M}$ NECA, respectively [80]. In NG108-15 cells, expressing both $A_{2 A} R$ and $A_{2 B} R$, the rate of desensitization for both receptor subtypes appeared similar, with a half-life of 15-20 min. Pretreatment with NECA of these cells $(0.1 \mathrm{mM}, 30 \mathrm{~min})$ reduced stimulation of adenylyl cyclase by $\mathrm{A}_{2 \mathrm{~B}} \mathrm{R}$ by approximately $50 \%[60,61]$.

Rat pheochromocytoma PC12 cells also endogenously express both $A_{2 A} R$ and $A_{2 B} R$. Prolonged exposure $(14 \mathrm{~h})$ to $100 \mathrm{nM}$ NECA or $1 \mu \mathrm{M}$ CGS21680 significantly inhibited the cAMP response of the cells to subsequent stimulation with the $\mathrm{A}_{2 \mathrm{~A}}$-selective agonist CGS21680. Although a 100fold higher NECA concentration is needed to stimulate the $A_{2 B} R$ compared to $A_{2 A} R$, Chern et al. found that the $A_{2 B}$ receptor cAMP response was also desensitized upon desensitization of the $A_{2 A}$ receptor. This observation can be explained by the fact that the $\mathrm{G}_{\mathrm{s} \alpha}$ protein level and the adenylyl cyclase activity were diminished upon long-term desensitization of the $\mathrm{A}_{2 \mathrm{~A}} \mathrm{R}$ by CGS21680 [59].

The domain in which the receptor resides is also important for desensitization events, according to Sitaraman et al. NECA $(10 \mu \mathrm{M})$ added to either the apical or basolateral side of T84 intestinal cells resulted in desensitization of the $\mathrm{A}_{2 \mathrm{~B}} \mathrm{R}$ on the corresponding side within 2$3 \mathrm{~h}$. However, whereas applying NECA to the apical side of the membrane had no effect on the basolateral $A_{2 B} R$, basolateral NECA induced a complete desensitization of the apical receptor. Since receptor trafficking may play a role in this cross-desensitization process, this effect may contribute to the desensitization and subsequent downregulation of the $\mathrm{A}_{2 \mathrm{~B}} \mathrm{R}$ [81].

Trincavelli et al. observed a very rapid desensitization $\left(\mathrm{t}_{1 / 2}=5 \mathrm{~min}\right)$ of $\mathrm{A}_{2 \mathrm{~B}} \mathrm{R}$ in a human astrocytoma cell line. Both $\mathrm{G}$ protein coupling efficiency and cAMP production were diminished after pretreatment of the cells with NECA in the presence of an $\mathrm{A}_{2 \mathrm{~A}} \mathrm{R}$-selective antagonist [82].

Mundell et al. reported that acute exposure of human airway smooth muscle (ASM) cells to adenosine receptor agonists resulted in a rapid accumulation of cAMP, most probably via $A_{2 B} R$. Treatment with adenosine deaminase (ADA) suggested that ASM cells produce adenosine which feeds back on the cells' $\mathrm{A}_{2 \mathrm{~B}}$ Rs, thereby regulating basal cAMP levels and inducing a small degree of $A_{2 B} R$ desensitization. Chronic treatment with adenosine agonists had a dual effect; both $\mathrm{A}_{2 \mathrm{~B}} \mathrm{R}$ desensitization and adenylyl cyclase sensitization (an increased responsiveness of adenylyl cyclase upon stimulation) were observed [83].

Haynes et al. [84] studied $\mathrm{A}_{2 \mathrm{~B}} \mathrm{R}$ desensitization in both pulmonary artery smooth muscle cells and a more integrated preparation, the isolated perfused lung. Pretreatment of the smooth muscle cells with NECA for 45 min abrogated the increase in cAMP response otherwise observed for both NECA and isoproterenol, suggesting heterologous desensitization. Indeed, experiments with cholera toxin showed that the desensitization took place at the level of the $G_{s}$ protein-adenylyl cyclase complex. In the lung preparation NECA, when dosed acutely, caused a rapid vasodilation, which was not observed when the tissue was treated again with the same compound $45 \mathrm{~min}$ after the first dose [84].

Taken together, these results suggest that desensitization of the $A_{2 B}$ receptor is a robust phenomenon, rather independent from the cell type or tissue in which it is expressed.

\section{Molecular mechanisms}

Effects of receptor mutations on desensitization and/or internalization

Matharu et al. studied the regions of the $\mathrm{A}_{2 \mathrm{~B}} \mathrm{R}$ which are responsible for the desensitization and internalization of the $A_{2 B} R$ [85]. For this purpose they introduced point mutations or deletions in the $\mathrm{C}$ terminus of the $\mathrm{A}_{2 \mathrm{~B}} \mathrm{R}$. Deleting the final two amino acids ( $\mathrm{Leu}^{330}$-stop) did not affect the internalization properties of the $A_{2 B} R$. The $\mathrm{Phe}^{328}$-stop and $\mathrm{Gln}^{325}$-stop mutants, however, were resistant to agonist-induced desensitization and internalization. GFP-tagged arrestin 2 did not translocate from the cytosol to the plasma membrane upon agonist stimulation of these two truncated receptors. From a single point mutation in the $\mathrm{C}$ terminus, Ser ${ }^{329} \mathrm{Gly}$, it became clear that this serine residue is responsible for the rapid agonist-induced desensitization and internalization. Surprisingly, a further deletion mutant $\operatorname{Ser}^{326}$-stop was able to undergo rapid agonistinduced desensitization and internalization; however, arrestin 2 was not attracted to the plasma membrane upon agonist stimulation. It appeared that internalization of this truncated receptor occurred via an arrestin- and clathrinindependent pathway, probably via caveolin-mediated internalization since the internalization of $\mathrm{Ser}^{326}$-stop was dynamin dependent. The destination of this truncated 
receptor was also different: a compartment close to the plasma membrane, instead of early endosomes. Whether the receptor will undergo rapid agonist-induced desensitization and internalization or influence the rate, extent and mechanism of internalization depends on specific sites in the $\mathrm{C}$ terminus of the $\mathrm{A}_{2 \mathrm{~B}} \mathrm{R}$ and can be influenced by their mutation or deletion.

\section{GRKs and arrestins}

The $A_{2 B} R$, endogenously expressed in NG108-15 cells, is desensitized through phosphorylation by GRK2. This GRK2 effect was selective for $A_{2 A} R$ and $A_{2 B} R$, since the other endogenously expressed receptors (secretin R and IPprostanoid R) were not desensitized in this way [68]. In addition, stable transfection of a dominant negative GRK2 (Lys220Arg) mutant in the NG108-15 cells reduced the NECA-induced (30 min, $100 \mu \mathrm{M})$ desensitization of the $\mathrm{A}_{2 \mathrm{~B}} \mathrm{R}$ by $50 \%$ [60]. Peters et al. studied the role of phosphorylation by PKA and PKC rather than GRK2 in agonist-induced desensitization in COS-7 cells transiently expressing the 5'-FLAG $\mathrm{A}_{2 \mathrm{~B}} \mathrm{R}$. They concluded that these second messenger-dependent kinases are not involved in $A_{2 B} R$ phosphorylation [80]. A similar conclusion for $A_{2 B} R$ phosphorylation in NG108-15 cells was reached by Mundell and Kelly [61]. Trincavelli et al. found that treatment of astrocytoma cells with TNF- $\alpha$ increased the $\mathrm{A}_{2 \mathrm{~B}} \mathrm{R}$ functional response, without changing receptor protein or mRNA levels. TNF- $\alpha$ treatment appeared to markedly reduce agonist-dependent receptor phosphorylation and also attenuated agonist-mediated $\mathrm{A}_{2 \mathrm{~B}} \mathrm{R}$ desensitization. These effects could be inhibited by the addition of the $\mathrm{A}_{2 \mathrm{~B}} \mathrm{R}$ antagonist MRS 1706 [82]. These findings resemble data obtained with the $\mathrm{A}_{2 \mathrm{~A}} \mathrm{R}$ (vide supra).

Mundell et al. found that within the arrestin family, both arrestin 2 and arrestin 3 are involved in the internalization process of the $\mathrm{A}_{2 \mathrm{~B}}$ receptor. Within $1 \mathrm{~min}$ of agonist exposure, both GFP-tagged arrestin isoforms were translocated to the plasma membrane. Longer agonist exposure (>10 min), however, revealed that only arrestin 2 colocalizes with the receptor in the early endosomes. One explanation for this may be a higher affinity of the $A_{2 B} R$ for arrestin 2 compared to arrestin 3. Interestingly, arrestins are not only involved in the internalization of the $\mathrm{A}_{2 \mathrm{~B}}$ receptor, but also in its recycling. It appeared that the expression of stable arrestin anti-sense constructs, reducing the levels of endogenous arrestins, not only resulted in less internalization of the receptors, but also impaired the recycling process significantly. In contrast to the internalization process, arrestin 3 induced a significantly faster rate of $\mathrm{A}_{2 \mathrm{~B}} \mathrm{R}$ recycling compared to arrestin 2 [86].

Penn et al. also studied the behaviour of GFP-tagged arrestins, now in human airway smooth muscle cells.
Arrestin 2 and arrestin 3 were able to reduce the cAMP production upon stimulation of endogenous $A_{2 B} R$ by NECA and stimulation of $\beta_{2}$-AR by isoproterenol. In addition, a punctate clustering was observed in the membrane upon exposure to either NECA $(100 \mu \mathrm{M})$ or isoproterenol $(1 \mu \mathrm{M})$, indicating that arrestins play a role in receptor trafficking. On the contrary, signalling and trafficking of the prostaglandin $\mathrm{E}_{2}-\mathrm{R}$, another endogenously expressed receptor, was not affected by arrestin 2 or arrestin $3[27]$.

\section{$A_{3}$ receptor}

Adenosine $A_{3}$ receptors $\left(A_{3} R\right)$ evoke considerable interest as novel drug targets to address cerebral/cardiac ischaemia, cancer, inflammation, asthma and chronic obstructive pulmonary disease. So far, potent and selective antagonists for the $\mathrm{hA}_{3} \mathrm{R}$ have been identified; the disadvantage however is that those antagonists show extremely low binding affinity for the rodent $A_{3} R$, typically 1,000 times lower than in humans. Since rodent models are essential for the pharmacological evaluation of new therapeutic agents, this forms a serious drawback.

In addition, the adenosine $A_{3}$ receptor $\left(A_{3} R\right)$ sequence holds a nuclear localization signal in its C-terminal tail [87]. This typical stretch of four amino acids (KKFK) in helix 8 may direct the receptor to the cell nucleus, not necessarily as a consequence of desensitization or internalization. This should be kept in mind when appreciating the studies described below.

\section{Cellular and physiological studies}

Ramkumar et al. studied the characteristics of rat $\mathrm{A}_{3} \mathrm{R}$, endogenously expressed on RBL-2H3 mast cells. In one of their experiments the authors pretreated the cells with NECA and found a partial desensitization of the initial $\mathrm{Ca}^{2+}$ response to NECA [88]. Trincavelli et al. studied the relationship between agonist-induced desensitization, internalization and resensitization of $\mathrm{hA}_{3} \mathrm{R}$ in transfected $\mathrm{CHO}$ cells. Agonist-induced endocytosis of $\mathrm{hA}_{3} \mathrm{R}$ was investigated by immunogold electron microscopy of plasma membranes and intracellular vesicles and shown to occur with a half-life of $17 \mathrm{~min}$. Subsequent removal of the agonist led to recycling of $90 \%$ of the receptor population to the cell surface, with a half-life of $35 \mathrm{~min}$. Short-term exposure to agonist caused rapid desensitization, as assessed in cAMP assays. Removal of the agonist led to resensitization of the cAMP signal to $90 \%$ of the original signal within $120 \mathrm{~min}$. Internalization did not affect signal transduction, as was demonstrated after blockade of internalization and recycling. Internalization occurred via 
clathrin-coated pits. These results show that $\mathrm{hA}_{3} \mathrm{R}$ undergoes agonist-induced endocytosis, which is not responsible for desensitization. Moreover, in the case of $\mathrm{hA}_{3} \mathrm{R}$, receptor sequestration rather than desensitization seems to be the first step in a cycle of internalization, dephosphorylation and recycling to the plasma membrane [89]. A similar cell line was used by Palmer et al. In stably transfected $\mathrm{CHO}$ cells prolonged treatment with NECA $(10 \mu \mathrm{M}, 20 \mathrm{~h})$ induced uncoupling of recombinant $h_{3} R$ from $G_{i}$ proteins and a functional desensitization. Upon this $A_{3} R$ desensitization, an approximately twofold increase in adenylyl cyclase activity was found in the presence or absence of forskolin. This sensitization of adenylyl cyclase activity was not caused by an altered level of inhibitory or stimulatory $G$ protein expression. The occurrence of the sensitization was also not due to new protein synthesis, but probably to an increased coupling efficiency between $\mathrm{G}_{\mathrm{s}}$ and adenylyl cyclase. Compared to control cells, long-term exposure of stably transfected CHO cells to NECA caused an increase in phosphorylation of the cAMP-responsive element binding protein upon addition of suboptimal concentrations of forskolin. The sensitization of adenylyl cyclase activity upon long-term treatment might provide a molecular basis for the observation that for several adenosine receptor-mediated events, acute agonist exposure produces opposite effects to those after chronic agonist treatment [90]. Ferguson et al. studied the fate of the rat $\mathrm{A}_{3} \mathrm{R}$ expressed in $\mathrm{CHO}$ cells. The receptors internalized rapidly after treatment with NECA or R-PIA over a time frame $\left(\mathrm{t}_{1}=10 \mathrm{~min}\right)$ that followed receptor phosphorylation $\left(\mathrm{t}_{1 / 2}=1 \mathrm{~min}\right)$ [91].

The desensitization, internalization and downregulation of $\mathrm{hA}_{3} \mathrm{R}$ was also investigated in human astrocytoma cells, natively expressing $\mathrm{hA}_{3} \mathrm{R}$. Short-term $(15 \mathrm{~min})$ exposure of the cells to $100 \mathrm{nM} \mathrm{Cl-IBMECA}$, an $\mathrm{A}_{3} \mathrm{R}$-selective agonist, caused rapid receptor desensitization, subsequently followed by receptor internalization within $30 \mathrm{~min}$. With the help of immunogold electron microscopy, the localization of the $A_{3} R$ was revealed. After $10 \mathrm{~min}$ of exposure, the $A_{3} R$ was found in smooth-surfaced pits and in uncoated vesicles in the cytoplasm. After $30 \mathrm{~min}$ of exposure, the $\mathrm{A}_{3} \mathrm{R}$ was found in vesicular endosomes. Upon removal of the agonist, resensitization of the $A_{3} R$ occurred within $120 \mathrm{~min}$ through receptor recycling to the cell surface. Long-term agonist exposure (1-24 h) resulted in a marked downregulation of $\mathrm{A}_{3} \mathrm{R}$ to $22 \pm 3 \%$ of control after $24 \mathrm{~h}$. In conclusion, multiple, temporally distinct and sequential processes are involved in the regulation of $\mathrm{hA}_{3} \mathrm{R}$ upon short- and long-term exposure to agonists [92].

$\mathrm{A}_{3}$ Rs were found to be highly expressed on murine B16F10 melanoma cells [93]. The authors examined the association between $\mathrm{A}_{3} \mathrm{R}$ trafficking and receptor functionality and tumour growth inhibition upon activation with the
$\mathrm{A}_{3} \mathrm{R}$-selective agonist IB-MECA. Exposure to $10 \mathrm{nM}$ IBMECA (5 min) led to rapid internalization of $A_{3} R$ to the cytosol, upon which receptors were directed to the endosomes for recycling or to lysosomes for degradation. The addition of $100 \mathrm{nM}$ MRS 1523 (5 min), an $\mathrm{A}_{3} \mathrm{R}$ antagonist, was able to counteract the internalization process as well as the modulation of the Wnt pathway leading to proliferation, thereby emphasizing the involvement of $\mathrm{A}_{3} \mathrm{R}$ in this process. When the melanoma cells were injected into nude mice, tumours rapidly developed. Tumour growth was significantly inhibited after administration of IB-MECA to the animals, paralleled by a decrease in $\mathrm{A}_{3} \mathrm{R}$ expression in tumour lesions. In hypoxic human A172 and U87MG glioblastoma cell lines it was found that adenosine upregulates the expression of hypoxia-inducible factor- $1 \alpha$ $(\mathrm{HIF}-1 \alpha)$ and vascular endothelial growth factor (VEGF) via the $A_{3}$ receptor. HIF- $1 \alpha$ is a key regulator in the development of tumours. The addition of the $\mathrm{A}_{3}$-antagonist MRE 3008F20 inhibited the adenosine-induced HIF-1 $\alpha$ and VEGF accumulation in these hypoxic cells, thereby showing a putative role in inhibiting tumour growth [94].

To circumvent the species differences mentioned in the introduction to the $A_{3} R$ section, Yamano et al. generated $A_{3} R$ humanized $\left(A_{3} A R^{h / h}\right)$ mice in which the $A_{3} R$ was replaced by its human counterpart. The expression level of $h A_{3} R$ in the humanized $\left(A_{3} A R^{h / h}\right)$ mice was equal to the expression levels of $A_{3} R$ in wild-type mice. $A_{3} R$ agonists were able to elevate the intracellular $\mathrm{Ca}^{2+}$ concentration in bone marrow-derived mast cells from the humanized $\left(A_{3} A^{h / h}\right)$ mice. However, the rate of $h A_{3} R$ internalization was markedly reduced compared with that of $\mathrm{mA}_{3} \mathrm{R}$ in these mast cells [95].

\section{Molecular mechanisms}

Receptor phosphorylation, GRKs and arrestins

Palmer and Stiles as well as Ferguson et al. investigated which amino acid residues in the $\mathrm{C}$ terminus are responsible and crucial for the rapid desensitization of the $A_{3} R[96,91]$. A triple mutant $\left(\mathrm{Thr}^{307}, \mathrm{Thr}^{318}\right.$ and $\mathrm{Thr}^{319}$ to Ala) exhibited dramatically reduced phosphorylation, desensitization and internalization of the rat $\mathrm{A}_{3} \mathrm{AR}$. Individual mutation of each Thr residue showed that $\mathrm{Thr}^{318}$ and $\mathrm{Thr}^{319}$ were the most important sites for phosphorylation. In addition, phosphorylation of $\mathrm{Thr}^{318}$ was necessary to observe phosphorylation of $\mathrm{Thr}^{319}$, but not vice versa. Moreover, changing $\mathrm{Thr}^{318}$ for a negatively charged residue (Glu) was not sufficient to retain phosphorylation at $\mathrm{Thr}^{319}$. Mutating two predicted palmitoylation sites, $\mathrm{Cys}^{302,305}$ to Ala resulted in agonistindependent basal phosphorylation of the rat $\mathrm{A}_{3} \mathrm{AR}$. Such findings strongly suggest that palmitoylation of these Cys 
residues is an important factor in controlling accessibility of the $\mathrm{C}$ terminus of the $\mathrm{A}_{3} \mathrm{R}$ in the process of recruiting GRKs. In fact, the palmitoylation sites are highly conserved between different species, e.g. rat, mouse, human, dog, sheep. Taking these results together, it appears that GRKmediated phosphorylation of the $\mathrm{A}_{3} \mathrm{R} C$ terminus follows a sequential mechanism, with the receptor palmitoyl moieties in an important regulatory role, and phosphorylation of $\mathrm{Thr}^{318}$ being particularly crucial as an essential first step. In an earlier study Palmer et al. replaced the carboxyl terminus of the $A_{1} R$ by that of the $A_{3} R$ [37]. This chimaeric construct was able to undergo agonist-stimulated phosphorylation and functional desensitization, similar to $\mathrm{A}_{3} \mathrm{R}$. It was also found that purified GRK2, GRK3 and GRK5 were all able to enhance agonist-dependent phosphorylation of $A_{3} R$ as well as the $A_{1}-A_{3}$ chimaera.

Trincavelli et al. studied the involvement of extracellularly regulated kinases (ERK1 and 2), members of the mitogen-activated protein kinase (MAPK) family, in $\mathrm{A}_{3} \mathrm{R}$ phosphorylation. It was found that within $5 \mathrm{~min}$ of exposure to $10 \mu \mathrm{M}$ NECA, ERK1 and 2 were already phosphorylated in $\mathrm{CHO}$ cells stably expressing $\mathrm{hA}_{3} \mathrm{R}$. An inhibitor of MAPK activation (PD98059) also caused inhibition of $\mathrm{A}_{3} \mathrm{R}$ phosphorylation, desensitization and internalization, probably by preventing the membrane translocation of GRK2. These results indicate that the MAPK cascade is involved in $\mathrm{A}_{3} \mathrm{R}$ regulation by a feedback mechanism which controls GRK2 activity and probably involves direct receptor phosphorylation [97].

The rat basophilic leukaemia cell $2 \mathrm{H} 3$ cell line (RBL$2 \mathrm{H} 3$ cells) endogenously expresses equal levels of arrestin 2 and arrestin 3. Both arrestin isoforms also have a high and comparable affinity for clathrin, thereby promoting agonistinduced internalization. RBL-2H3 cells also endogenously express a high level of $\mathrm{A}_{3} \mathrm{R}$, which, however, neither recruited arrestin 3 nor arrestin 2 upon stimulation with NECA. Also no changes in $A_{3} R$ distribution were observed. One explanation is that $A_{3} R$ follows an endocytic mechanism upon agonist stimulation that does not involve arrestin-mediated clathrin-coated pit internalization. Another possible explanation is that arrestin recruitment was below the limit of detection in the RBL-2H3 cells [98]. Ferguson et al. observed that upon phosphorylation of $A_{3} R$ by GRK arrestin 3 is redistributed into punctate vesicles both at the plasma membrane and within the cytoplasm. Nevertheless, these authors also noticed that there was no colocalization between $\mathrm{A}_{3} \mathrm{R}$ and arrestin 3 [47].

\section{Conclusions}

The adenosine receptor subtypes are differentially regulated when exposed to agonist treatment. $\mathrm{A}_{1}$ Rs are not (readily) phosphorylated and slowly internalize with a typical halflife of several hours. This feature may cause less than average tachyphylaxis upon chronic agonist administration, for instance in type II diabetes. $\mathrm{A}_{2 \mathrm{~A}} \mathrm{R}$ and $\mathrm{A}_{2 \mathrm{~B}} \mathrm{R}$ show much faster downregulation with similar kinetics, usually $<1 \mathrm{~h}$ for short-term desensitization. Agonists for the $\mathrm{A}_{2 \mathrm{~A}}$ receptor, currently profiled in wound healing, may thus suffer from declining efficacy upon chronic administration, in contrast to those for the $A_{1}$ receptor. The $A_{3} R$ undergoes even faster downregulation, often a matter of minutes. The latter receptor also holds a nuclear localization signal in its carboxy terminal tail, possibly obscuring true agonistinduced downregulation. The fast desensitization of the $\mathrm{A}_{3} \mathrm{R}$ after agonist exposure may be therapeutically equivalent to antagonist occupancy of the receptor.

\section{References}

1. Palmer TM, Stiles GL (1995) Adenosine receptors. Neuropharmacology 34:683-694

2. Perez DM, Karnik SS (2005) Multiple signaling states of Gprotein-coupled receptors. Pharmacol Rev 57:147-161

3. Klinger M, Freissmuth M, Nanoff C (2002) Adenosine receptors: $\mathrm{G}$ protein-mediated signalling and the role of accessory proteins. Cell Signal 14:99-108

4. Palmer TM, Stiles GL (1997) Identification of an $A_{2 A}$ adenosine receptor domain specifically responsible for mediating short-term desensitization. Biochemistry 36:832-838

5. Fredholm BB, IJzerman AP, Jacobson KA, Klotz KN, Linden J (2001) International Union of Pharmacology. XXV. Nomenclature and classification of adenosine receptors. Pharmacol Rev 53:527552

6. Yaar R, Jones MR, Chen JF, Ravid K (2005) Animal models for the study of adenosine receptor function. J Cell Physiol 202:9-20

7. Jacobson KA, Gao ZG (2006) Adenosine receptors as therapeutic targets. Nat Rev Drug Discov 5:247-264

8. Beukers MW, Meurs I, Ijzerman AP (2006) Structure-affinity relationships of adenosine $A_{2 B}$ receptor ligands. Med Res Rev 26:667-698

9. Müller CE (2000) Adenosine receptor ligands-recent developments part I. Agonists. Curr Med Chem 7:1269-1288

10. Klotz KN (2000) Adenosine receptors and their ligands. Naunyn Schmiedebergs Arch Pharmacol 362:382-391

11. Franco R, Ciruela F, Casado V, Cortes A, Canela EI, Mallol J, Agnati LF, Ferre S, Fuxe K, Lluis C (2005) Partners for $A_{1}$ Rs. J Mol Neurosci 26:221-232

12. Schwarzschild MA, Agnati L, Fuxe K, Chen JF, Morelli M (2006) Targeting adenosine $\mathrm{A}_{2 \mathrm{~A}}$ receptors in Parkinson's disease. Trends Neurosci 29:647-654

13. Minghetti L, Greco A, Potenza RL, Pezzola A, Blum D, Bantubungi K, Popoli P (2007) Effects of the adenosine $A_{2 A}$ receptor antagonist SCH 58621 on cyclooxygenase-2 expression, glial activation, and brain-derived neurotrophic factor availability in a rat model of striatal neurodegeneration. J Neuropathol Exp Neurol 66:363-371

14. Dall'Igna OP, Fett P, Gomes MW, Souza DO, Cunha RA, Lara DR (2007) Caffeine and adenosine $A_{2 A}$ receptor antagonists prevent beta-amyloid (25-35)-induced cognitive deficits in mice. Exp Neurol 203:241-245 
15. Zhao Z, Yaar R, Ladd D, Cataldo LM, Ravid K (2002) Overexpression of $\mathrm{A}_{3}$ adenosine receptors in smooth, cardiac, and skeletal muscle is lethal to embryos. Microvasc Res 63:61-69

16. Young HW, Molina JG, Dimina D, Zhong H, Jacobson M, Chan LN, Chan TS, Lee JJ, Blackburn MR (2004) $A_{3}$ adenosine receptor signaling contributes to airway inflammation and mucus production in adenosine deaminase-deficient mice. J Immunol 173:1380-1389

17. Gessi S, Cattabriga E, Avitabile A, Gafa' R, Lanza G, Cavazzini L, Bianchi N, Gambari R, Feo C, Liboni A, Gullini S, Leung E, MacLennan S, Borea PA (2004) Elevated expression of $\mathrm{A}_{3}$ adenosine receptors in human colorectal cancer is reflected in peripheral blood cells. Clin Cancer Res 10:5895-5901

18. Milligan G, Kostenis E (2006) Heterotrimeric G-proteins: a short history. Br J Pharmacol 147(Suppl 1):S46-S55

19. Pierce KL, Premont RT, Lefkowitz RJ (2002) Seven-transmembrane receptors. Nat Rev Mol Cell Biol 3:639-650

20. Moro S, Gao ZG, Jacobson KA, Spalluto G (2006) Progress in the pursuit of therapeutic adenosine receptor antagonists. Med Res Rev 26:131-159

21. Yabuuchi K, Kuroiwa M, Shuto T, Sotogaku N, Snyder GL, Higashi H, Tanaka M, Greengard P, Nishi A (2006) Role of adenosine $A_{1}$ receptors in the modulation of dopamine $D_{1}$ and adenosine $A_{2 A}$ receptor signaling in the neostriatum. Neuroscience 141:19-25

22. Cordeaux Y, Briddon SJ, Megson AE, McDonnell J, Dickenson JM, Hill SJ (2000) Influence of receptor number on functional responses elicited by agonists acting at the human adenosine $A_{1}$ receptor: evidence for signaling pathway-dependent changes in agonist potency and relative intrinsic activity. Mol Pharmacol 58:1075-1084

23. Cordeaux Y, Ijzerman AP, Hill SJ (2004) Coupling of the human $A_{1}$ adenosine receptor to different heterotrimeric $G$ proteins: evidence for agonist-specific $\mathrm{G}$ protein activation. Br J Pharmacol 143:705-714

24. Fredholm BB, Arslan G, Halldner L, Kull B, Schulte G, Wasserman W (2000) Structure and function of adenosine receptors and their genes. Naunyn Schmiedebergs Arch Pharmacol 362:364-374

25. Ferguson SSG (2001) Evolving concepts in G protein-coupled receptor endocytosis: the role in receptor desensitization and signaling. Pharmacol Rev 53:1-24

26. Chini B, Parenti M (2004) G-protein coupled receptors in lipid rafts and caveolae: how, when and why do they go there? J Mol Endocrinol 32:325-338

27. Penn RB, Pascual RM, Kim YM, Mundell SJ, Krymskaya VP, Panettieri RA Jr, Benovic JL (2001) Arrestin specificity for G protein-coupled receptors in human airway smooth muscle. J Biol Chem 276:32648-32656

28. Maudsley S, Martin B, Luttrell LM (2005) The origins of diversity and specificity in $\mathrm{G}$ protein-coupled receptor signaling. J Pharmacol Exp Ther 314:485-494

29. Moore MS, Mahaffey DT, Brodsky FM, Anderson RG (1987) Assembly of clathrin-coated pits onto purified plasma membranes. Science 236:558-563

30. Sorkin A (2004) Cargo recognition during clathrin-mediated endocytosis: a team effort. Curr Opin Cell Biol 16:392-399

31. Reiter E, Lefkowitz RJ (2006) GRKs and beta-arrestins: roles in receptor silencing, trafficking and signaling. Trends Endocrinol Metab 17:159-165

32. Burgueno J, Canela EI, Mallol J, Lluis C, Franco R, Ciruela F (2004) Mutual regulation between metabotropic glutamate type $1 \alpha$ receptor and caveolin proteins: from traffick to constitutive activity. Exp Cell Res 300:23-34

33. Reiter E, Lefkowitz RJ (2006) GRKs and beta-arrestins: roles in receptor silencing, trafficking and signaling. Trends Endocrinol Metab 17:159-165
34. Lefkowitz RJ, Rajagopal K, Whalen EJ (2006) New roles for beta-arrestins in cell signaling: not just for seven-transmembrane receptors. Mol Cell 24:643-652

35. Ramkumar V, Olah ME, Jacobson KA, Stiles GL (1991) Distinct pathways of desensitization of $\mathrm{A}_{1}$ - and $\mathrm{A}_{2}$-adenosine receptors in $\mathrm{DDT}_{1}$ MF-2 cells. Mol Pharmacol 40:639-647

36. Nie Z, Mei Y, Ramkumar V (1997) Short term desensitization of the $\mathrm{A}_{1}$ adenosine receptors in $\mathrm{DDT}_{1} \mathrm{MF}-2$ cells. Mol Pharmacol 52:456-464

37. Palmer TM, Benovic JL, Stiles GL (1996) Molecular basis for subtype-specific desensitization of inhibitory adenosine receptors. Analysis of a chimeric $\mathrm{A}_{1}-\mathrm{A}_{3}$ adenosine receptor. J Biol Chem 271:15272-15278

38. Klaasse EC, van den Hout G, Roerink SF, de Grip WJ, Ijzerman AP, Beukers MW (2005) Allosteric modulators affect the internalization of human adenosine $\mathrm{A}_{1}$ receptors. Eur J Pharmacol 522:1-8

39. Vendite D, Sanz JM, Lopez-Alanon DM, Vacas J, Andres A, Ros M (1998) Desensitization of $A_{1} R$-mediated inhibition of adenylyl cyclase in cerebellar granule cells. Neurochem Res 23:211-218

40. Wetherington JP, Lambert NA (2002) Differential desensitization of responses mediated by presynaptic and postsynaptic $A_{1}$ adenosine receptors. J Neurosci 22:1248-1255

41. Coelho JE, Rebola N, Fragata I, Ribeiro JA, de Mendonca A, Cunha RA (2006) Hypoxia-induced desensitization and internalization of $\mathrm{A}_{1} \mathrm{Rs}$ in the rat hippocampus. Neuroscience 138:11951203

42. Parsons WJ, Stiles GL (1987) Heterologous desensitization of the inhibitory $A_{1}$ adenosine receptor-adenylate cyclase system in rat adipocytes. Regulation of both $\mathrm{N}_{\mathrm{s}}$ and $\mathrm{N}_{\mathrm{i}}$. J Biol Chem 262:841847

43. Longabaugh JP, Didsbury J, Spiegel A, Stiles GL (1989) Modification of the rat adipocyte $\mathrm{A}_{1}$ adenosine receptor-adenylate cyclase system during chronic exposure to an $\mathrm{A}_{1}$ adenosine receptor agonist: alterations in the quantity of $\mathrm{G}_{\mathrm{s} \alpha}$ and $\mathrm{G}_{\mathrm{i} \alpha}$ are not associated with changes in their mRNAs. Mol Pharmacol 36:681688

44. Ruiz A, Sanz JM, Gonzalez Calero G, Fernandez M, Andres A, Cubero A, Ros M (1996) Desensitization and internalization of $\mathrm{A}_{1} \mathrm{Rs}$ in rat brain by in vivo treatment with R-PIA: involvement of coated vesicles. Biochim Biophys Acta 1310:168-174

45. Ruiz MA, Albasanz JL, Leon D, Ros M, Andres A, Martin M (2005) Different modulation of inhibitory and stimulatory pathways mediated by adenosine after chronic in vivo agonist exposure. Brain Res 1031:211-221

46. Gao Z, Ni Y, Szabo G, Linden J (1999) Palmitoylation of the recombinant human $A_{1}$ adenosine receptor: enhanced proteolysis of palmitoylation-deficient mutant receptors. Biochem J 342:387395

47. Ferguson G, Watterson KR, Palmer TM (2002) Subtype-specific regulation of receptor internalization and recycling by the carboxyl-terminal domains of the human $\mathrm{A}_{1}$ and rat $\mathrm{A}_{3}$ adenosine receptors: consequences for agonist-stimulated translocation of arrestin3. Biochemistry 41:14748-14761

48. Iacovelli L, Franchetti R, Grisolia D, De Blasi A (1999) Selective regulation of $\mathrm{G}$ protein-coupled receptor-mediated signaling by $\mathrm{G}$ protein-coupled receptor kinase 2 in FRTL-5 cells: analysis of thyrotropin, $\alpha_{1 \mathrm{~B}}$-adrenergic, and $\mathrm{A}_{1}$ adenosine receptor-mediated responses. Mol Pharmacol 56:316-324

49. Saura CA, Mallol J, Canela EI, Lluis C, Franco R (1998) Adenosine deaminase and $\mathrm{A}_{1}$ adenosine receptors internalize together following agonist-induced receptor desensitization. J Biol Chem 273:17610-17617

50. Escriche M, Burgueño J, Ciruela F, Canela EI, Mallol J, Enrich C, Lluís C, Franco R (2003) Ligand-induced caveolae-mediated internalization of $A_{1}$ adenosine receptors: morphological evidence 
of endosomal sorting and receptor recycling. Exp Cell Res 285:72-90

51. Ginés S, Ciruela F, Burgueño J, Casado V, Canela EI, Mallol J, Lluis C, Franco R (2001) Involvement of caveolin in ligandinduced recruitment and internalization of $\mathrm{A}_{1}$ adenosine receptor and adenosine deaminase in an epithelial cell line. Mol Pharmacol 59:1314-1323

52. Ciruela F, Saura C, Canela EI, Mallol J, Lluis C, Franco R (1997) Ligand-induced phosphorylation, clustering, and desensitization of $\mathrm{A}_{1}$ adenosine receptors. Mol Pharmacol 52:788-797

53. Sarrio S, Casado V, Escriche M, Ciruela F, Mallol J, Canela EI, Lluis C, Franco R (2000) The heat shock cognate protein hsc73 assembles with $A_{1}$ adenosine receptors to form functional modules in the cell membrane. Mol Cell Biol 20:5164-5174

54. Dunwiddie TV, Diao L, Kim HO, Jiang JL, Jacobson KA (1997) Activation of hippocampal $A_{3}$ Rs produces a desensitization of $A_{1}$ receptor-mediated responses in rat hippocampus. J Neurosci 17:607-614

55. Lopes LV, Cunha RA, Ribeiro JA (1999) Cross talk between $A_{1}$ and $\mathrm{A}_{2 \mathrm{~A}}$ adenosine receptors in the hippocampus and cortex of young adult and old rats. J Neurophysiol 82:3196-3203

56. Ciruela F, Casado V, Rodrigues RJ, Lujan R, Burgueno J, Canals M, Borycz J, Rebola N, Goldberg SR, Mallol J, Cortes A, Canela EI, Lopez-Gimenez JF, Milligan G, Lluis C, Cunha RA, Ferre S, Franco R (2006) Presynaptic control of striatal glutamatergic neurotransmission by adenosine $\mathrm{A}_{1}-\mathrm{A}_{2 \mathrm{~A}}$ receptor heteromers. J Neurosci 26:2080-2087

57. Selley DE, Cassidy MP, Martin BR, Sim-Selley LJ (2004) Longterm administration of $\Delta^{9}$-tetrahydrocannabinol desensitizes $\mathrm{CB}_{1}$-, adenosine $\mathrm{A}_{1^{-}}$, and $\mathrm{GABA}_{\mathrm{B}}$-mediated inhibition of adenylyl cyclase in mouse cerebellum. Mol Pharmacol 66:1275-1284

58. Ginés S, Hillion J, Torvinen M, Le Crom S, Casado V, Canela EI, Rondin S, Lew JY, Watson S, Zoli M, Agnati LF, Verniera P, Lluis C, Ferre S, Fuxe K, Franco R (2000) Dopamine $D_{1}$ and $A_{1} R s$ form functionally interacting heteromeric complexes. Proc Natl Acad Sci U S A 97:8606-8611

59. Chern Y, Lai HL, Fong JC, Liang Y (1993) Multiple mechanisms for desensitization of $\mathrm{A}_{2 \mathrm{~A}}$ adenosine receptor-mediated cAMP elevation in rat pheochromocytoma PC12 cells. Mol Pharmacol 44:950-958

60. Mundell SJ, Benovic JL, Kelly E (1997) A dominant negative mutant of the $G$ protein-coupled receptor kinase 2 selectively attenuates adenosine $\mathrm{A}_{2}$ receptor desensitization. Mol Pharmacol 51:991-998

61. Mundell SJ, Kelly E (1998) Evidence for co-expression and desensitization of $\mathrm{A}_{2 \mathrm{~A}}$ and $\mathrm{A}_{2 \mathrm{~B}}$ adenosine receptors in NG108-15 cells. Biochem Pharmacol 55:595-603

62. Palmer TM, Gettys TW, Jacobson KA, Stiles GL (1994) Desensitization of the canine $\mathrm{A}_{2 \mathrm{a}}$ adenosine receptor: delineation of multiple processes. Mol Pharmacol 45:1082-1094

63. Conti A, Lozza G, Monopoli A (1997) Prolonged exposure to 5'$\mathrm{N}$-ethylcarboxamidoadenosine (NECA) does not affect the adenosine $\mathrm{A}_{2 \mathrm{~A}}$-mediated vasodilation in porcine coronary arteries. Pharmacol Res 35:123-128

64. Castillo-Melendez M, Krstew E, Lawrence AJ, Jarrott B (1994) Presynaptic adenosine $A_{2 A}$ receptors on soma and central terminals of rat vagal afferent neurons. Brain Res 652:137-144

65. Helfman CC, Zhong H, Barraco RA, Anderson GF (1996) The effects of $5^{\prime}-N$-ethylcarboxamidoadenosine on evoked release of $\left[{ }^{3} \mathrm{H}\right]$ serotonin in the rat nucleus tractus solitarius. Neurosci Lett 213:61-65

66. Barraco RA, Helfman CC, Anderson GF (1996) Augmented release of serotonin by adenosine $A_{2 a}$ receptor activation and desensitization by CGS 21680 in the rat nucleus tractus solitarius. Brain Res 733:155-161
67. Rekik M, Mustafa JS (2003) Modulation of $\mathrm{A}_{2 \mathrm{~A}}$ adenosine receptors and associated $\mathrm{G}_{\alpha \mathrm{s}}$ proteins by $\mathrm{ZM} 241385$ treatment of porcine coronary artery. J Cardiovasc Pharmacol 42:736-744

68. Mundell SJ, Luty JS, Willets J, Benovic JL, Kelly E (1998) Enhanced expression of $G$ protein-coupled receptor kinase 2 selectively increases the sensitivity of $\mathrm{A}_{2 \mathrm{~A}}$ adenosine receptors to agonist-induced desensitization. Br J Pharmacol 125:347-356

69. Khoa ND, Postow M, Danielsson J, Cronstein BN (2006) Tumor necrosis factor- $\alpha$ prevents desensitization of $\mathrm{G} \alpha_{\mathrm{s}}$-coupled receptors by regulating GRK2 association with the plasma membrane. Mol Pharmacol 69:1311-1319

70. Mundell SJ, Kelly E (1998) The effect of inhibitors of receptor internalization on the desensitization and resensitization of three $\mathrm{G}_{\mathrm{s}}$-coupled receptor responses. Br J Pharmacol 125:1594-1600

71. Burgueño J, Blake DJ, Benson MA, Tinsley CL, Esapa CT, Canela EI, Penela P, Mallol J, Mayor F Jr, Lluis C, Franco R, Ciruela $F$ (2003) The $A_{2 A} R$ interacts with the actin-binding protein alpha-actinin. J Biol Chem 278:37545-37552

72. Gsandtner I, Freissmuth M (2006) A tail of two signals: the C terminus of the $\mathrm{A}_{2 \mathrm{~A}}$-adenosine receptor recruits alternative signaling pathways. Mol Pharmacol 70:447-449

73. Gsandtner I, Charalambous C, Stefan E, Ogris E, Freissmuth M, Zezula J (2005) Heterotrimeric G protein-independent signaling of a $\mathrm{G}$ protein-coupled receptor. Direct binding of ARNO/cytohesin2 to the carboxyl terminus of the $\mathrm{A}_{2 \mathrm{~A}}$ adenosine receptor is necessary for sustained activation of the ERK/MAP kinase pathway. J Biol Chem 280:31898-31905

74. Salmi P, Chergui K, Fredholm BB (2005) Adenosine-dopamine interactions revealed in knockout mice. J Mol Neurosci 26:239-244

75. Canals M, Marcellino D, Fanelli F, Ciruela F, de Benedetti P, Goldberg SR, Neve K, Fuxe K, Agnati LF, Woods AS, Ferre S, Lluis C, Bouvier M, Franco R (2003) Adenosine $A_{2 A}$-dopamine $\mathrm{D}_{2}$ receptor-receptor heteromerization: qualitative and quantitative assessment by fluorescence and bioluminescence energy transfer. J Biol Chem 278:46741-46749

76. Tang Y, Demarest KT (2005) Distinctive and synergistic signaling of human adenosine $\mathrm{A}_{2 \mathrm{~A}}$ and dopamine $\mathrm{D}_{2 \mathrm{~L}}$ receptors in $\mathrm{CHO}$ cells. J Recept Signal Transduct Res 25:159-179

77. Vortherms TA, Watts VJ (2004) Sensitization of neuronal $A_{2 A}$ adenosine receptors after persistent $\mathrm{D}_{2}$ dopamine receptor activation. J Pharmacol Exp Ther 308:221-227

78. Hillion J, Canals M, Torvinen M, Casado V, Scott R, Terasmaa A, Hansson A, Watson S, Olah ME, Mallol J, Canela EI, Zoli M, Agnati LF, Ibanez CF, Lluis C, Franco R, Ferre S, Fuxe K (2002) Coaggregation, cointernalization, and codesensitization of $\mathrm{A}_{2 \mathrm{~A}} \mathrm{Rs}$ and dopamine $\mathrm{D}_{2}$ receptors. J Biol Chem 277:18091-18097

79. Carriba P, Ortiz O, Patkar K, Justinova Z, Stroik J, Themann A, Müller C, Woods AS, Hope BT, Ciruela F, Casadó V, Canela EI, Lluis C, Goldberg SR, Moratalla R, Franco R, Ferré S (2007) Striatal adenosine $\mathrm{A}_{2 \mathrm{~A}}$ and cannabinoid $\mathrm{CB}_{1}$ receptors form functional heteromeric complexes that mediate the motor effects of cannabinoids. Neuropsychopharmacology 32:2249-2259

80. Peters DM, Gies EK, Gelb CR, Peterfreund RA (1998) Agonistinduced desensitization of $\mathrm{A}_{2 \mathrm{~B}}$ adenosine receptors. Biochem Pharmacol 55:873-882

81. Sitaraman SV, Si-Tahar M, Merlin D, Strohmeier GR, Madara JL (2000) Polarity of $\mathrm{A}_{2 \mathrm{~B}}$ adenosine receptor expression determines characteristics of receptor desensitization. Am J Physiol Cell Physiol 287:1230-1236

82. Trincavelli ML, Marroni M, Tuscano D, Ceruti S, Mazzola A, Mitro N, Abbracchio MP, Martini C (2004) Regulation of $A_{2 B}$ adenosine receptor functioning by tumour necrosis factor a in human astroglial cells. J Neurochem 91:1180-1190

83. Mundell SJ, Olah ME, Panettieri RA, Benovic JL, Penn RB (2001) Regulation of G protein-coupled receptor-adenylyl cyclase 
responsiveness in human airway smooth muscle by exogenous and autocrine adenosine. Am J Respir Cell Mol Biol 24:155-163

84. Haynes J, Obiako B, Babal P, Stevens T (1999) 5-(N-ethylcarboxamido)adenosine desensitizes the $\mathrm{A}_{2 \mathrm{~B}}$-adenosine receptor in lung circulation. Am J Physiol 276:H1877-H1883

85. Matharu AL, Mundell SJ, Benovic JL, Kelly E (2001) Rapid agonist-induced desensitization and internalization of the $A_{2 B}$ adenosine receptor is mediated by a serine residue close to the COOH terminus. J Biol Chem 276:30199-30207

86. Mundell SJ, Matharu AL, Kelly E, Benovic JL (2000) Arrestin isoforms dictate differential kinetics of $\mathrm{A}_{2 \mathrm{~B}}$ adenosine receptor trafficking. Biochemistry 39:12828-12836

87. Lee DK, Lanca AJ, Cheng R, Nguyen T, Ji XD, Gobeil F Jr, Chemtob S, George SR, O'Dowd BF (2004) Agonist-independent nuclear localization of the Apelin, angiotensin AT1, and bradykinin B2 receptors. J Biol Chem 279:7901-7908

88. Ramkumar V, Stiles GL, Beaven MA, Ali H (1993) The $A_{3}$ adenosine receptor is the unique adenosine receptor which facilitates release of allergic mediators in mast cells. J Biol Chem 268:16887-16890

89. Trincavelli ML, Tuscano D, Cecchetti P, Falleni A, Benzi L, Klotz KN, Gremigni V, Cattabeni F, Lucacchini A, Martini C (2000) Agonist-induced internalization and recycling of the human $\mathrm{A}_{3}$ adenosine receptors: role in receptor desensitization and resensitization. J Neurochem 75:1493-1501

90. Palmer TM, Harris CA, Coote J, Stiles GL (1997) Induction of multiple effects on adenylyl cyclase regulation by chronic activation of the human $\mathrm{A}_{3}$ adenosine receptor. Mol Pharmacol 52:632-640

91. Ferguson G, Watterson KR, Palmer TM (2000) Subtype-specific kinetics of inhibitory adenosine receptor internalization are determined by sensitivity to phosphorylation by $G$ proteincoupled receptor kinases. Mol Pharmacol 57:546-552

92. Trincavelli ML, Tuscano D, Marroni M, Falleni A, Gremigni V, Ceruti S, Abbracchio MP, Jacobson KA, Cattabeni F, Martini C (2002) $\mathrm{A}_{3}$ adenosine receptors in human astrocytoma cells: agonistmediated desensitization, internalization, and down-regulation. Mol Pharmacol 62:1373-1384

93. Madi L, Bar-Yehuda S, Barer F, Ardon E, Ochaion A, Fishman P (2003) $\mathrm{A}_{3}$ adenosine receptor activation in melanoma cells: association between receptor fate and tumor growth inhibition. J Biol Chem 278:42121-42130

94. Merighi S, Benini A, Mirandola P, Gessi S, Varani K, Leung E, Maclennan S, Borea PA (2006) Adenosine modulates vascular endothelial growth factor expression via hypoxia-inducible factor1 in human glioblastoma cells. Biochem Pharmacol 72:19-31

95. Yamano $K$, Inoue $M$, Masaki $S$, Saki $M$, Ichimura $M$, Satoh $M$ (2005) Human $\mathrm{A}_{3} \mathrm{R}$ leads to intracellular $\mathrm{Ca}^{2+}$ mobilization but is insufficient to activate the signaling pathway via phosphoinositide 3-kinase gamma in mice. Biochem Pharmacol 70:1487-1496

96. Palmer TM, Stiles GL (2000) Identification of threonine residues controlling the agonist-dependent phosphorylation and desensitization of the rat $\mathrm{A}_{3}$ adenosine receptor. Mol Pharmacol 57:539545

97. Trincavelli ML, Tuscano D, Marroni M, Klotz KN, Lucacchini A, Martini C (2002) Involvement of mitogen protein kinase cascade in agonist-mediated human $\mathrm{A}_{3}$ adenosine receptor regulation. Biochim Biophys Acta 19:55-62

98. Santini F, Penn RB, Gagnon AW, Benovic JL, Keen JH (2000) Selective recruitment of arrestin-3 to clathrin-coated pits upon stimulation of G protein-coupled receptors. J Cell Sci 113:24632470 